\title{
A Contribution Towards the Life-History of the Spur-Dog.
}

\author{
By \\ C. F. Hickling, M.A., \\ Fisheries Laboratory, Lowestoit. \\ With 16 Figures in the Text.
}

THE object in publishing these notes on the Spur-Dog, Acanthias vulgaris Risso, is to show the close resemblance, in the distribution of the sizes and sexes, between this fish and the Hake. The Hake will be dealt with in a future paper.

The work has been done during voyages in which the Hake has been the principal object of research. The data on Dogfish have therefore been collected at odd times during a very busy programme on the Hake, and this must be my apology for inadequacy or discontinuity in the figures presented. I would especially thank my colleague, Mr. W. Johnston, and my friend, Mr. C. E. D. Enoch, for their willing help in this entirely unofficial work; and Mr. J. Armitage Robertson for his help in the arrangement of the text.

\section{SIZE, SEX, AND DEPTH.}

A good series of measurements were made during the cruises of the Ministry of Agriculture and Fisheries' research vessel, George Bligh, to the western hake grounds in August, 1928. The position of the stations may be seen in the chart in Figure 1.

The material was collected by using a full-size Vigneron-Dahl trawl, with the cod-end covered by fine-meshed shrimp-netting. One can therefore be certain that no small specimens can have slipped through the meshes and have thus been lost.

The stations worked fall into three main groups, as follows :-

Banks-Westward Group. Stations " between the Banks," Cockburn Bank, and on the Westward Ground.

Fastnet Group. Stations Bantry Bay, Galley Head, and Inner and Outer Fastnet.

Galway-Bull Group. Stations " below the Bull," Galway Bay, i.e. off the Aran Islands, and, finally, inside the Aran Islands. 
Station 18, about midway between the Banks-Westward and the Fastnet groups of stations, is considered separately.

Where a depth is referred to, the mean depth of the hauls which supplied the data is meant. The data will be found in the Appendix, Table XIII, where the actual frequency at each 5-cm. group is denoted by an upright, the percentage frequency by an italic numeral.

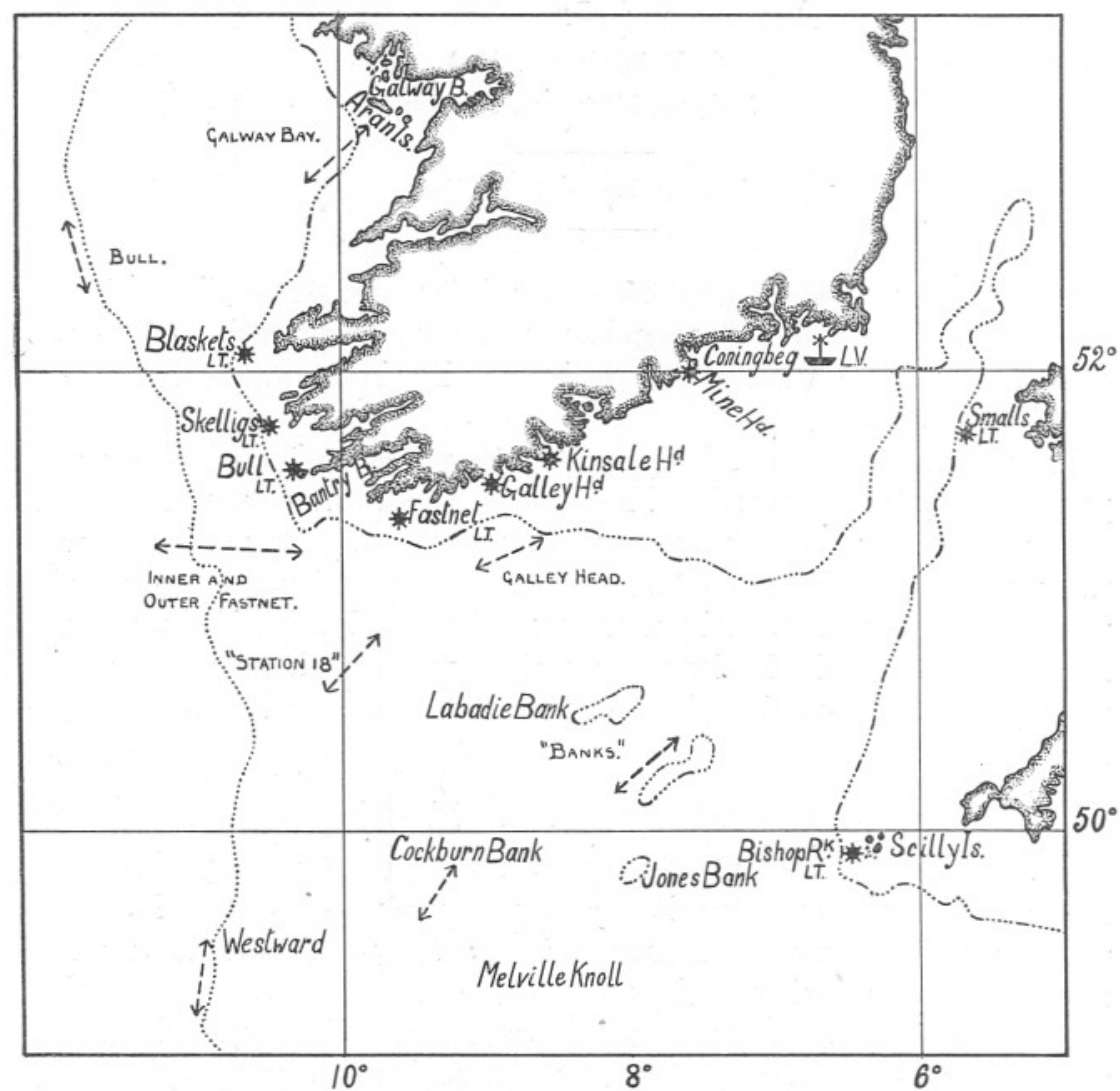

FIG. 1.-Map of South-Western Area, showing the approximate position of the stations sampled, except Bantry Bay, and Inside Aran Islands (Galway Bay).

\section{The Fastnet Stations.}

In Figure 2 four pairs of curves are drawn. The pecked line refers to males, the continuous line to females. The curves show the percentage of the fish measured, which were present in each 5-cm. group, each sex being separately considered. The grouping was as follows: more than 25 but less than $30 \mathrm{~cm}$., more than 30 but less than $35 \mathrm{~cm}$., etc. In the figures, the plotted point is at the mid-point of the group. 
The uppermost pair of curves refer to the fish measured in Bantry Bay, at a mean depth of 30 fathoms. Both males and females show a wellmarked mode at a length, calculated by Wollaston's "three point" method (Wollaston and Hodgson, 1929), of $34 \cdot 21$ and $34 \cdot 20 \mathrm{~cm}$. respectively. Both curves show a second mode at about $42 \mathrm{~cm}$. (the exact modal length cannot be calculated by Wollaston's method), and a third mode, at $67.5 \mathrm{~cm}$. in the female, and $68.5 \mathrm{~cm}$. in the male. The curves show that the males in the sample tend to be larger than the females, for, in the first mode, $47 \cdot 8 \%$ of the females, but only $39 \cdot 8 \%$ of

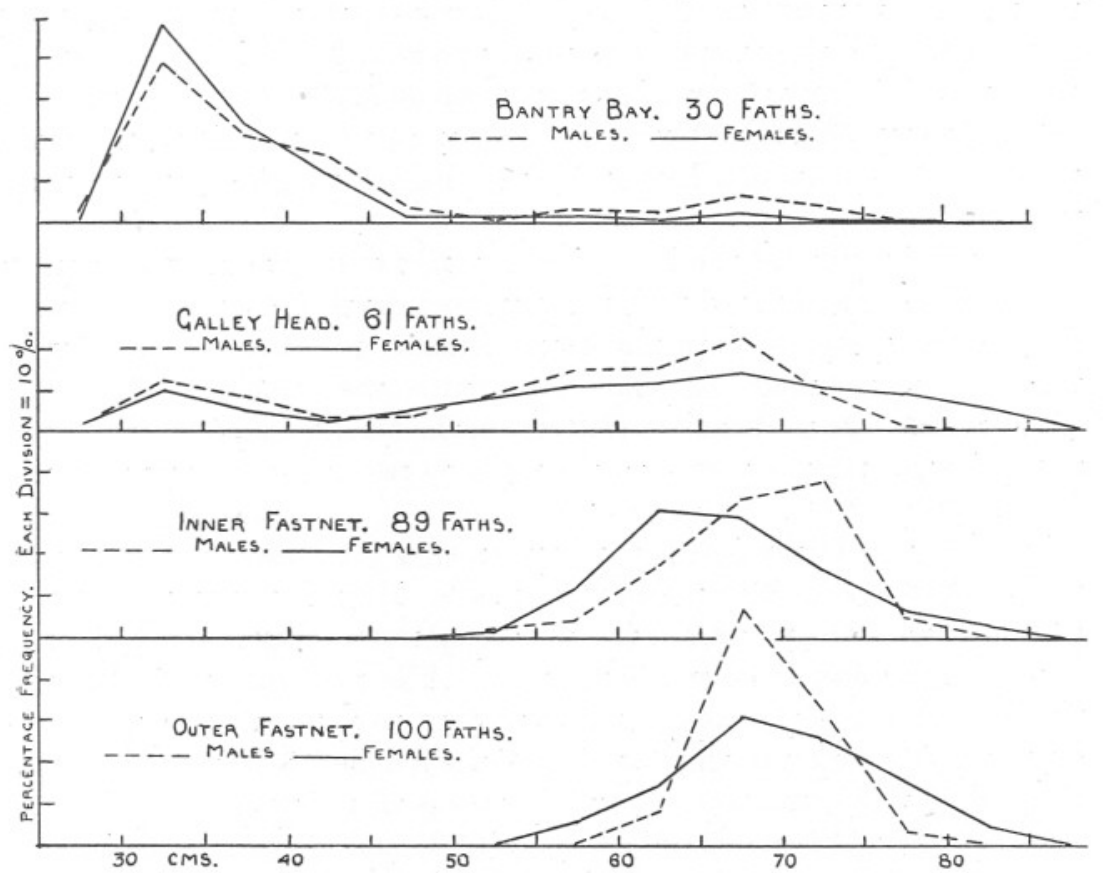

FIG. 2.-The Fastnet Region. Percentage frequencies in the 5-cm. groups of measured fish. George Bligh, August, 1928. Data from Table XIII.

the males, in the second mode, at about $42 \mathrm{~cm} ., 12 \cdot 0 \%$ of the females, but $15 \cdot 2 \%$ of the males, and in the third mode, at $67 \mathrm{~cm}$., only $2 \cdot 2 \%$ of the females, but $6 \cdot 3 \%$ of the males, are present. In confirmation of this, the median for the females is found to be $35 \cdot 4 \mathrm{~cm}$., for the males, $37 \cdot 3 \mathrm{~cm}$.

The two curves for the Galley Head measurements, at a mean depth of 61 fathoms, show clearly how, with the deeper water, the size of the dogfish has increased. The first mode, at a calculated length of $33.58 \mathrm{~cm}$. in the female, and $34.60 \mathrm{~cm}$. in the male, has a slightly lower modal length than in Bantry Bay, but, on the other hand, only $10.8 \%$ of the females and $11 \cdot 3 \%$ of the males are present at this mode. The Bantry 
mode at $42 \mathrm{~cm}$. is not indicated, but there are two distinct modes, one at about $58 \mathrm{~cm}$., the other at $66.52 \mathrm{~cm}$. in the female (calculated modal length) and $66.67 \mathrm{~cm}$. in the male. Both these modes are foreshadowed in the Bantry sample, but very few fish are present in them. In the Galley Head sample they predominate, with $14.7 \%$ of the females and $23.0 \%$ of the males. In this sample also, therefore, there is a tendency for the males to be larger than the females; this may be seen in the higher percentage of males than of females in the modes at 58 and $66 \mathrm{~cm}$.; but in the medians, which are $62.7 \mathrm{~cm}$. for females, and $60 \cdot 0 \mathrm{~cm}$. for males, the reverse is apparent. This is due, however, to the number of very large females in the sample. As the Appendix, Table XIII, shows, no fewer than $5 \cdot 8 \%$ of the females are between 80 and $84 \mathrm{~cm}$. in length, and $3.5 \%$ between 85 and $89 \mathrm{~cm}$. As a later section will show, these are pregnant females which have migrated inshore to give birth to their young.

The two curves for the Inner Fastnet measurements show a further increase in size associated with the increased depth (89 fathoms). Small fish are not present; both males and females give an unimodal curve, with a calculated modal length of $64.81 \mathrm{~cm}$. in the female, and $70.33 \mathrm{~cm}$. in the male. The medians are $65.9 \mathrm{~cm}$. in the female, and $69 \cdot 2 \mathrm{~cm}$. in the male. In this sample, therefore, the males were distinctly larger than the females.

Finally, the Outer Fastnet measurements (100 fathoms) also give unimodal curves for both males and females. Here, however, the females are larger than the males, for the calculated modal lengths are $69 \cdot 17 \mathrm{~cm}$. in the female, and $68.93 \mathrm{~cm}$. in the male. The medians are 69.9 in the female, and 68.9 in the male. It is important to notice that, in the deepest water, 100 fathoms, there are $5 \%$ of the females at 80 to $84 \mathrm{~cm}$., and $1.4 \%$ at 85 to $89 \mathrm{~cm}$., whereas at 89 fathoms there are only $2.9 \%$ of the females at 80 to $84 \mathrm{~cm}$, and $0.7 \%$ at 85 to $89 \mathrm{~cm}$.

In these four samples from the Fastnet group of stations, therefore, we may see the progressive increase in length of the dogfish with increase in depth, manifesting itself in $(a)$ a movement of the modal lengths to the right, $(b)$ an increasingly higher proportion of the fish at the higher modes, and $(c)$ an increasingly higher median.

\section{The Banks-Westward Stations.}

In Figure 3 are drawn three pairs of curves. These refer to the samples collected on the three stations comprising the Banks-Westward group (Figure 1). As the Appendix, Table XIII, shows, the data from these stations are less abundant than those from the Fastnet group of stations, but their interpretation is no less clear and unequivocal. In Figure 3, 
as in Figure 2, the pecked line refers to the males, the continuous line to the females.

In the Banks sample (69 fathoms) two modes are seen, with calculated modal lengths of $33.55 \mathrm{~cm}$., and $55.30 \mathrm{~cm}$. in the female, and $33.80 \mathrm{~cm}$. and $52.18 \mathrm{~cm}$. in the male. The second modal length is therefore slightly higher in the female than in the male; on the other hand, in the first mode $33.8 \%$ of the females, but only $18.4 \%$ of the males are present, and in the second mode, $11.5 \%$ of the females, but $21.9 \%$ of the males. Thus, at this station, as at the Bantry Bay, Galley Head, and Inner Fastnet stations, the males present have a greater size than the females. This is

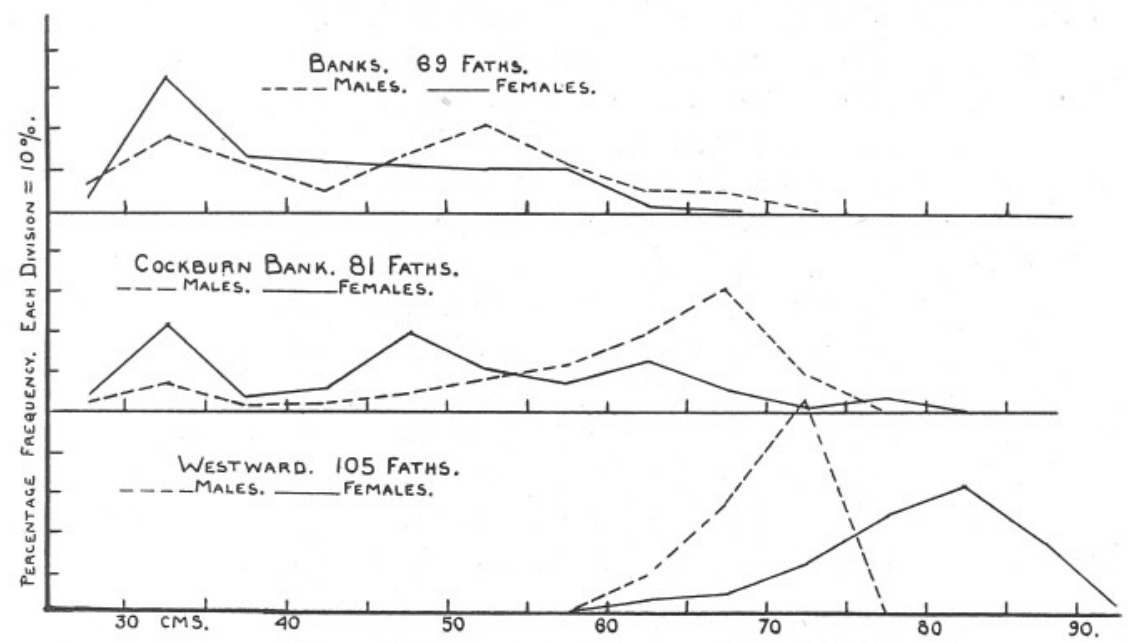

FIG. 3.-The Banks-Westward Region. Percentage frequencies in the 5-cm. groups of measured fish. George Bligh, August, 1928. Data from Table XIII.

further shown by the medians, namely, $39.5 \mathrm{~cm}$. in the female, and $47 \cdot 8 \mathrm{~cm}$. in the male.

The measurements made on the Cockburn Bank (81 fathoms) show that, in this deeper water, the length of the fish of both sexes has increased. Three distinct modes are shown by the curve for females, at calculated modal lengths of $32.37 \mathrm{~cm}$., $48.32 \mathrm{~cm}$., and $63.07 \mathrm{~cm}$. The first of these modes is plainly identical with that shown at $33.55 \mathrm{~cm}$. in the Banks sample, but, at 81 fathoms, only $21.5 \%$ of the females are present at this mode, as compared with $33.8 \%$ at 69 fathoms, while at the second and third modes, at 81 fathoms, $19.5 \%$ and $12.7 \%$ of the females are present. The males show two distinct modes, which give calculated modal lengths of $32.31 \mathrm{~cm}$. and $66.37 \mathrm{~cm}$. The first of these is identical with the first of the modes in the curve for the females, but only $7 \cdot 3 \%$ of the males are present at this mode, as compared with $21.5 \%$ of the females. The second mode in the curve for males, at $66 \cdot 37 \mathrm{~cm}$., contains 
no fewer than $30.6 \%$ of the males. Here again, therefore, the males in the sample are distinctly longer than the females in the sample, and the medians show this well, that for the males being $63 \cdot 1 \mathrm{~cm}$., for the females, $48.9 \mathrm{~cm}$.

Finally, the Westward sample shows curves of the same type as the Outer Fastnet sample in Figure 2. The females are distinctly larger than the males, the curves for both sexes are unimodal, with calculated modal lengths of $81.79 \mathrm{~cm}$. in the females, and $71.40 \mathrm{~cm}$. in the males. The medians are $81.0 \mathrm{~cm}$. in the females, and $70.5 \mathrm{~cm}$. in the males.

In the Banks-Westward series of stations there is shown the progressive increase in size of the dogfish of both sexes, with increase of depth, and, except in the Westward sample, the larger size of the males, as compared with the females, in any given sample. When the Banks-Westward stations are compared with the Fastnet stations, however, three points arise which must be noted, as they will be referred to later.

Firstly, there is a different relation to depth in the two groups of stations. The Banks curves, when compared with the Galley Head curves, show, in spite of the closely similar depth, a smaller size of dogfish; this can be best expressed by comparing the medians, which are $39.5 \mathrm{~cm}$. in the female, and $47.8 \mathrm{~cm}$. in the male, in the Banks sample, at 69 fathoms; but $62.7 \mathrm{~cm}$. and $60.0 \mathrm{~cm}$. in the males and females respectively, in the Galley Head sample, at 61 fathoms. A comparison of the Inner Fastnet (89 fathoms) with the Cockburn Bank (81 fathoms) shows the same phenomenon.

Secondly, no such shallow water was worked in the Banks-Westward group of stations as was worked in Bantry Bay (30 fathoms), but, on the whole, small newly-born dogfish were much scarcer in the BanksWestward than in the Fastnet group of stations, and had a smaller size. The modal lengths were $33.5 \mathrm{~cm}$. and $33.8 \mathrm{~cm}$. in females and males in the Banks sample, but $34 \cdot 2 \mathrm{~cm}$. in male and female in the Bantry sample. The difference, though slight, may be significant.

Thirdly, whereas, in the Fastnet group of stations, the largest females tended to be well represented in the shallow water stations, such as Bantry Bay, and especially Galley Head, in the Banks-Westward stations they are almost absent from the Banks and Cockburn Bank stations. On the other hand, they were concentrated in the deep water on the Westward ground to a much greater degree than on the Fastnet grounds at approximately the same depth. The impression is given that, in the Fastnet region, there had been a migration of the large females into shallow water, which had not yet taken place, or had only just begun, on the Banks-Westward stations at the time of the voyages. 


\section{The Galway-Bull Stations.}

As the Appendix shows, ${ }^{*}$ dogfish were very scarce on the Bull grounds, probably on account of the comparatively great depths fished there. The few specimens taken were found in the shallowest hauls (98 and 105 fathoms). The distribution of Acanthias with depth has been discussed elsewhere (Hickling, 1928), and it was shown that, in the Faroe-Shetland Channel, and off the West coast of Scotland, this fish was taken at every depth from $90-100$ to $500-520$ fathoms. The scarcity of dogfish in the deeper water on the Bull and Westward grounds may well be due to a regional, or, much more probably, a seasonal, variation in distribution.

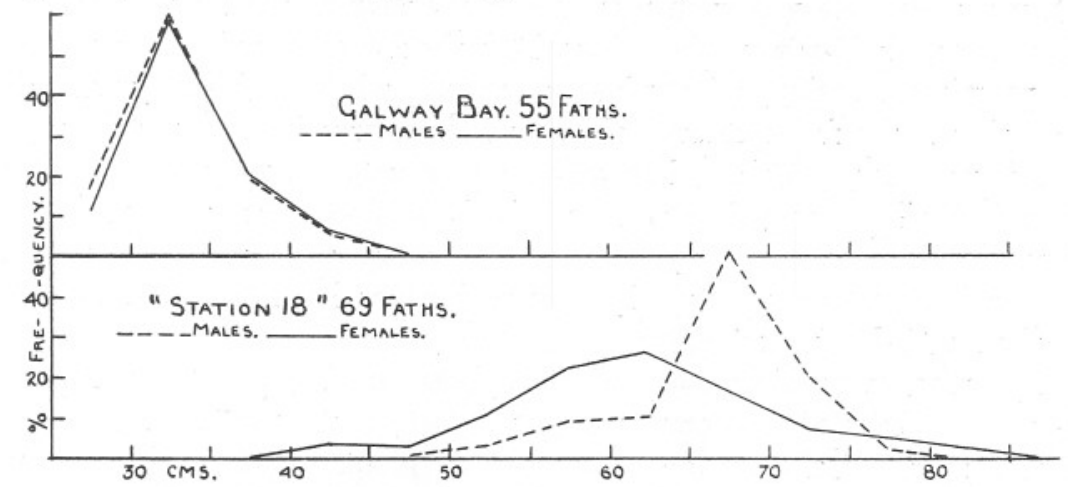

Fig. 4.-Galway Bay and Station 18. Percentage frequencies in the 5-cm. groups of measured fish. George Bligh, August, 1928. Data from Table XIII.

The 22 dogfish taken on the Bull grounds were, with five exceptions, between 60 and $90 \mathrm{~cm}$. in length, but the sample is too small to be worth further discussion.

The Galway Bay sample consisted almost wholly of young newly-born fish, as Figure 4 shows. There is a single mode, at a calculated modal length of $32.99 \mathrm{~cm}$. in the females, and $32.75 \mathrm{~cm}$. in the males. The curves for male and females, however, fit more closely than in any other sample. Besides these young fish, there were six large females of 70 to $93 \mathrm{~cm}$.

The third station, at 21 fathoms inside the landlocked waters of Galway Bay, was only sampled with a single haul of one hour's duration. This haul yielded 38 dogfish, which showed a length-distribution as follows :-

\begin{tabular}{lrrrrrrrrrl} 
Length & 25 & 30 & 35 & $40-$ & -70 & 75 & 80 & 85 & 90 & $95 \mathrm{~cm}$. \\
& to & to & to & to & to & to & to & to & to & to \\
& 29 & 34 & 39 & 44 & 74 & 79 & 84 & 89 & 94 & $99 \mathrm{~cm}$. \\
Frequency & 1 & 8 & 6 & $7-$ & -2 & 2 & 4 & 5 & 2 & 1 \\
& & \multicolumn{7}{c}{ * Table XVIII. }
\end{tabular}


The dogfish found in this very shallow water, therefore, fell into two sharply defined groups, the one, of small fish between 25 and $44 \mathrm{~cm}$., the other, of large fish between 70 and $99 \mathrm{~cm}$. Of the large fish, all but one were females.

A comparison has already been made between the Banks-Westward and the Fastnet groups of stations, and the conclusion was drawn that, among the large females, there was a migration inshore, which had not yet commenced in the Banks-Westward region, but was well advanced in the Fastnet region. It may be suggested that, in the Galway-Bull region, this inward migration of large and, as we shall see in a later section, pregnant females, was even more advanced than in the Fastnet region. For in very shallow water in Galway Bay, the fish consisted almost wholly of pregnant females and newly-born young, while in deeper water, in 55 fathoms, the fish consisted almost wholly of newly-born young, with a few pregnant females. The inshore migration of pregnant females, therefore, which, according to Travis Jenkins (1925), bear their young in very shallow water of 3 to 6 fathoms, is complete in the Galway-Bull region, is far advanced in the Fastnet region, but has hardly commenced in the Banks-Westward region.

The very great abundance of newly-born dogfish in Galway Bay is further evidence of this completion of the birth of the young. They were abundant at 55 fathoms in the Galway-Bull region, whereas, in the Fastnet region, they were most abundant at 30 fathoms, and comparatively scarce at 61 fathoms. This difference is probably the consequence of the earlier birth of the young in the former region, for, according to Travis Jenkins (loc. cit.), the young dogfish move away from shallow water shortly after birth.

The sample of dogfish taken at Station 18, midway between the BanksWestward and the Fastnet regions, furnishes percentage frequency-curves which are shown in the lower part of Figure 4. Both males and females show one predominant mode, at calculated modal lengths of $61 \cdot 12 \mathrm{~cm}$. in the female, and $68.12 \mathrm{~cm}$. in the male. The medians are $61.4 \mathrm{~cm}$. in the female, and $67 \cdot 7 \mathrm{~cm}$. in the male. This sample, therefore, furnishes further evidence of the larger size of the males at any given depth, such as has already been shown to be the case in both the Banks-Westward and Fastnet regions.

Both males and females show a mode at a lower length also, indicated by a flattening of the curves at about $45 \mathrm{~cm}$. in the female, and $58 \mathrm{~cm}$. in the male.

When the frequency-curves are compared with the series in Figures 2 and 3 , it is clear that the sample from Station 18 more closely resembles the Fastnet samples than the Banks-Westward samples, having regard to the depth at which the sample from Station 18 was fished. 


\section{The Sex-Ratio.}

Figures 2, 3, and 4 have represented the percentage frequency-curves of each sex considered separately. They therefore give no information as to the relative numbers of the sexes. Table XIII in the Appendix will show that the sex-ratio shows considerable variation in the samples, but is related to depth in such a way, that, down to a certain depth, the percentage of males increases, but, beyond that depth, decreases, until, in the deepest water, females form the great majority of the fish. The sex-ratios must be interpreted in the light of the length-distributions.

In the Banks-Westward region, the percentage of females was as follows :-

$\begin{array}{lrr}\text { Banks Station } & 69 \text { fathoms } & 54 \cdot 9 \% \text { females. } \\ \text { Cockburn Bank Station } & 81 \text { fathoms } & 37 \cdot 8 \% \text { females. } \\ \text { Westward Station } & 105 \text { fathoms } & 84 \cdot 8 \% \text { females. }\end{array}$

In the Fastnet region, the percentage of females was as follows :-

$\begin{array}{lrl}\text { Bantry Bay Station } & 30 \text { fathoms } & 59 \cdot 2 \% \text { females. } \\ \text { Galley Head Station } & 61 \text { fathoms } & 61 \cdot 3 \% \text { females. } \\ \text { Inner Fastnet Station } & 89 \text { fathoms } & 69 \cdot 9 \% \text { females. } \\ \text { Outer Fastnet Station } & 100 \text { fathoms } & 88 \cdot 0 \% \text { females. }\end{array}$

At Station 18 there were $52 \cdot 2 \%$ females, and in Galway Bay 56.9\% females.

It will be clear, from what has been said in the foregoing pages, that, in both males and females, there is a segregation according to size, such that the larger fish tend to be found in deeper water. Since in any given sample from shallower water the males tend to be larger than the females, the males are distributed in shallower water than the females.

Ford (1921), whose work will be constantly referred to in this paper, found that male and female dogfish are born in approximately equal numbers, and at the same length. The segregation of males in shallower water than the females will therefore tend to result in a sex-ratio, except in very shallow water, of more than $50 \%$ females. For example, in the Galway Bay sample, from a depth of 55 fathoms, the dogfish, which were, by their length, plainly newly-born, already showed $56.9 \%$ of females, and in Bantry Bay, where conditions were much the same, $59 \cdot 2 \%$ females. This difference in the distribution of the sexes is the first factor affecting the sex-ratio.

But the females grow to a much greater length than the males. Ford's data show that the largest male examined during his work was $83 \mathrm{~cm}$., but his largest female was $110 \mathrm{~cm}$. in length. My own figures, as in Table XIII, show the same fact equally clearly. Therefore, since females 
grow to a greater length than the males, and since the dogfish, other things being equal, are segregated according to size, with increase of depth, in the deepest water we should expect to find only big fish, and therefore chiefly female fish. This may be seen in the Westward and Outer Fastnet samples, where the percentage of females is respectively $84 \cdot 1$ and $88 \cdot 0$. This is the second factor affecting the sex-ratio, but it also acts in a somewhat unexpected way, as the next section will show.

The smaller size of the males is very well known as a general phenomenon among fishes. In the case of the Plaice (Wallace, 1907), the Cod (Saemundsson, 1923), and the Hake (Birtwistle and Lewis, 1924; Belloc, 1922) at least, it is due to a failure on the part of the males to maintain the rapid rate of growth shown by the females. The older year-groups among the males of these fish are therefore compressed into a much narrower range of length than the females, and, although Wallace rightly suggests that male Plaice are more viable than the females, there will clearly tend to be a region in the scale of length where few year-groups of females, but many year-groups of males are present. At these lengths the males will tend to be more abundant than the females. In the case of the Dogfish, we have seen that the fish are distributed by size according to depth. Therefore there will be a certain depth at which males will predominate over the females. This predominance may be seen in the Cockburn Bank sample, in which there are only $37.8 \%$ of females.

This should be regarded as the normal distribution of the sexes, with depth, in the Spurdog. In the shallowest water there should be a slight predominance of males, then a region where there is a slight predominance of females, then a somewhat restricted region where males greatly predominate, and finally, at still greater depths, a gradually increasing predominance of females. It is, therefore, hardly possible to speak of the sex-ratio among dogfish as though this were a constant; it will clearly vary with depth, and also, almost certainly, with season.

But it has also been shown that there is a shoreward migration of pregnant females. The presence of these females, in any numbers, must tend to reverse the sex-ratio in those regions where males would, on hypothetical grounds, predominate. In the Galley Head sample, and, to a lesser extent, in the Inner Fastnet sample, these pregnant females were present in some abundance, hence none of the stations in the Fastnet series shows such a predominance of males as the Cockburn Bank Station, where the inward migration of the pregnant females had not commenced.

This alteration of the hypothetical sex-ratio in dogfish by the inward migration of the pregnant females reaches its extreme, of course, in the very shallow station inside Galway Bay, at 21 fathoms, in which, of the larger group of fish, $93 \cdot 8 \%$ were females. 
For comparison with these results, data collected during the exploratory voyages of the Florence Brierley of Fleetwood, in March and April, 1927, are of value, and afford good confirmation. Three cautionary remarks must be made. Firstly, the material is usually much scantier than that available from the stations of the George Bligh; secondly, an ordinary commercial cod-end was used, without a covering of shrimpmesh; and thirdly, the shallowest water worked was 96 fathoms.

In Figure 5 are plotted the points representing the variation in sexratio, with increase of depth, as shown by the Florence Brierley samples. The abscissa represents the depth in fathoms, the ordinate, the percentage of females. The data will be found in the Appendix,

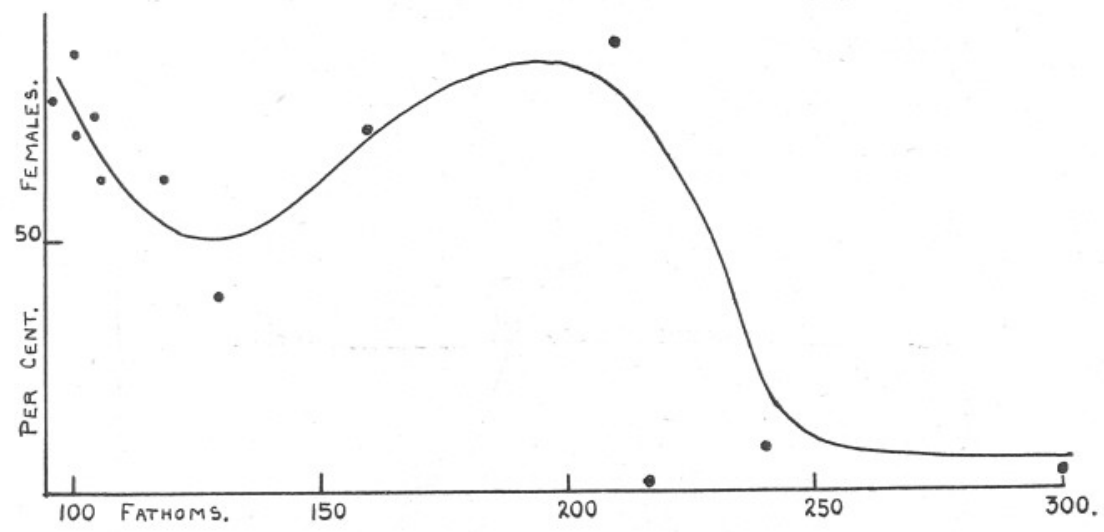

FIg. 5.-Variation in sex-ratio with depth. Florence Brierley, April, 1927. Data in Table XIV.

Table XIV. A line is drawn through the plotted points, to show the general trend.

It is evident that, from the shallowest water worked down to about 130 fathoms, the percentage of females decreases. It then increases from 130 to about 200 fathoms. This fluctuation is perfectly understandable from what has been said earlier in this section. There is a region where, for the reasons there stated, the males must tend to predominate, and, in these samples, 130 fathoms is, roughly, the centre of this region. Beyond this depth, females become dominant, until $90 \%$ of females is found at 210 fathoms. Moreover, the pregnant females were most abundant in the deep water ; at this time, therefore, there was no inshore migration of pregnant females to mask the concentration of the males at the intermediate depth.

Something quite new shown by Figure 5 is the presence, in very deep water, of shoals of dogfish consisting exclusively of mature males. It may be taken as certain that these males were living pelagically, and were caught during the hauling or shooting of the trawl. 


\section{Sexual Maturity, Pregnancy, and the Embryo.}

Ford (loc. cit.) finds that, in the male dogfish, sexual maturity sets in at about 59-60 cm., but, in the female, not until between 70 and $80 \mathrm{~cm}$. The smallest pregnant female in his samples was $72.8 \mathrm{~cm}$. in length, but he concludes that a female "before becoming mature, undergoes an extended adolescent period in which her first set of eggs are developing in the ovaries. The specimens under $70 \mathrm{~cm}$. in length were quite immature, and no conspicuous eggs were present in the ovaries."

In Figure 6 are drawn two curves, showing the percentage, respectively, of mature and immature males at lengths between 52 and $66 \mathrm{~cm}$. The earliest mature fish was $55 \mathrm{~cm}$. in length, the latest immature fish $63 \mathrm{~cm}$.

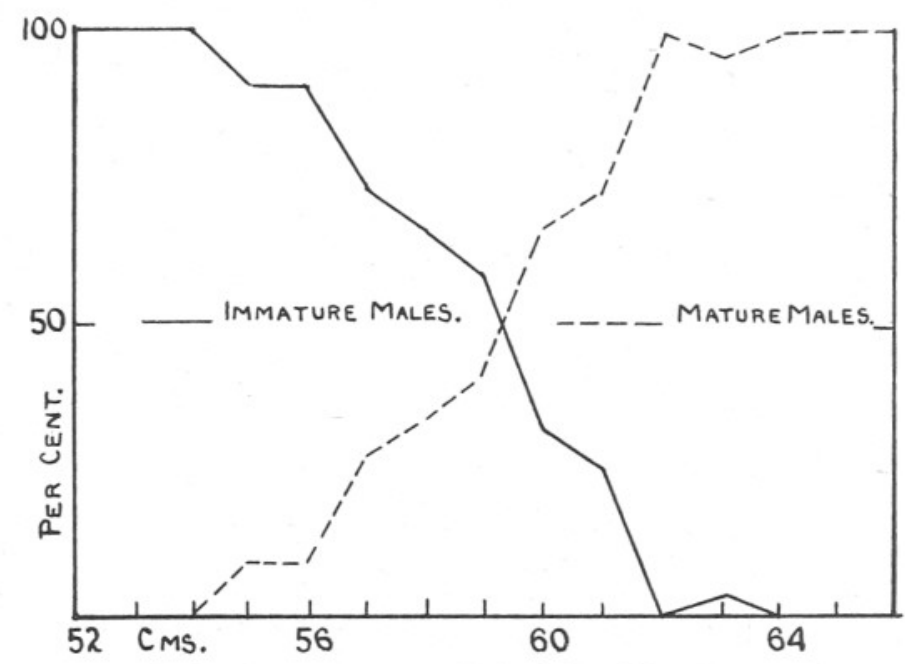

FIG. 6.-Onset of maturity in male dogfish. All stations combined, George Bligh, August, 1929. Data in Table XV.

The curves cross at some point between 59 and $60 \mathrm{~cm}$., so that I can entirely confirm Ford. The data are given in the Appendix, Table XV.

The smallest pregnant female found in my samples was $64 \mathrm{~cm}$. in length, but I can confirm Ford's conclusion that pregnancy generally sets in between 75 and $80 \mathrm{~cm}$. In Figure 7 the percentage of pregnant females in the total females, at each 5-cm. group, is shown graphically. The data are to be found in the Appendix, Table XVI. The curve shows its most rapid rise from $75-79$ to $80-84 \mathrm{~cm}$., but it never reaches $100 \%$ owing to the presence of newly-spent females.

In Table I the pregnant females found at each station are represented by a black dot. It should be said in passing, that these data on pregnancy are based on the females dissected for the weighing experiments to be described in the latter half of this paper. 


\section{TABLe I.}

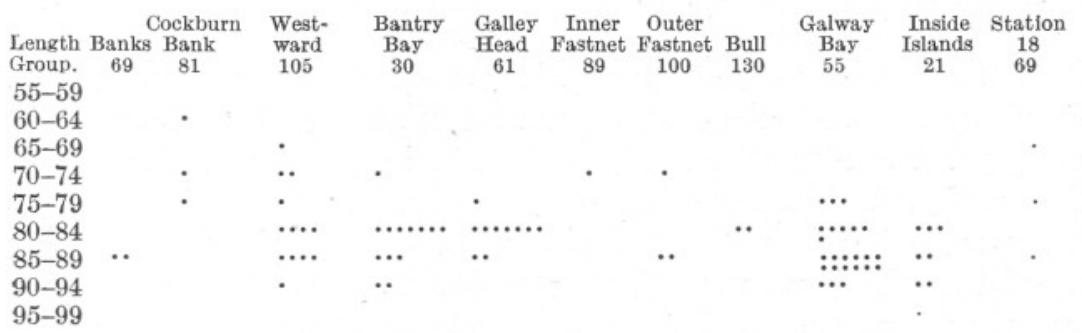

The table shows the occurrence of pregnancy in the various samples quite sufficiently clearly, without the necessity of weighting for the size of the samples.

Pregnant females were few in the Banks and Cockburn Bank samples,

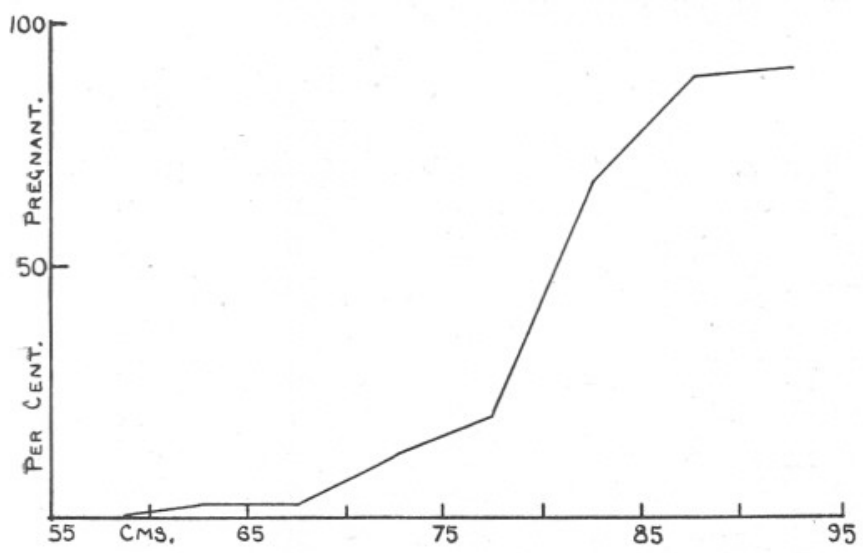

Fig. 7.-Onset of pregnancy in female dogfish. All stations, George Bligh, August, 1928. Data in Table XVI.

but plentiful in the Westward sample. In the Fastnet group of stations, pregnant females were plentiful in the Bantry Bay and Galley Head samples, but scarce in the Inner and Outer Fastnet stations, and from the sample from Station 18. In the Galway-Bull region, pregnant females were scarce in the Bull sample, but plentiful in the Galway Bay sample, and in the shallow water inside the Aran Islands.

Recalling what has already been said about the distribution of large females among the stations, it is clear that the distribution of pregnant females is identical with this, and that the inward migration of large females, deduced by an inspection of the frequency-curves, is, in reality, a shoreward migration of pregnant females to bear their young in shallow water. This shoreward migration was far advanced in the Galway-Bull 
region, was taking place in the Fastnet region, but had not yet commenced in the Banks-Westward region.

This may be illustrated further by showing the percentage of pregnant females among the potentially pregnant females in the different samples. For this purpose, all females greater than $75 \mathrm{~cm}$. are regarded as potentially pregnant. The data are given in Table II in the text below. In many of the samples, the data are thin, in others, fairly adequate, but in all regions one may see that the pregnant females predominate in the shallow water, and that, in the deeper water, in those regions where the inward migration is farthest advanced (the Inner and Outer Fastnet grounds for example), those mature females remaining are non-pregnant. These are probably newly-spent fish, which have returned to deep water after bearing their young.

TABLe II.

\begin{tabular}{|c|c|c|c|c|}
\hline Percentage of Pre & $\begin{array}{l}\text { FEM } \\
\text { S }_{\text {AM }}\end{array}$ & $\begin{array}{l}\text { ES IN THE } \\
\text { ES. }\end{array}$ & GeORGe & LIGH " \\
\hline Station. & Depth. & $\begin{array}{l}\text { No. of } \\
\text { Females } \\
\text { greater than } \\
75 \mathrm{~cm}\end{array}$ & No. & $\stackrel{\%}{\%}$ \\
\hline Banks & 69 & 2 & 2 & 100 \\
\hline Cockburn Bàk & 81 & 3 & 3 & 100 \\
\hline Westward & 105 & 15 & 13 & 87 \\
\hline Bantry Bay & 30 & 20 & 13 & 65 \\
\hline Galley Head & 61 & 19 & 10 & 53 \\
\hline Inner Fastnet & 89 & 7 & 1 & 14 \\
\hline Outer Fastnet & 100 & 19 & 3 & 16 \\
\hline Bull & 130 & 8 & 2 & 25 \\
\hline Galway Bay & 55 & 33 & 32 & 97 \\
\hline Inside Aran Islands & 21 & 9 & 8 & 88 \\
\hline Station 18 & 69 & 7 & 3 & 43 \\
\hline
\end{tabular}

The results of the voyages of the George Bligh, therefore, show us the distribution of pregnant females at the time of the birth of the young, which, as Ford finds, takes place from September onwards. The voyages of the Florence Brierley, on the other hand, show that, in the early spring, the pregnant females are found in the deeper water. As the Appendix, Table XIV, shows, the four well-sampled hauls of March 29th and 30th, and March 31st and April 2nd, give clear indication of the shoaling of the pregnant females in deeper water. This, however, is simply the consequence of the segregation of the larger sizes of dogfish in the deeper water, already demonstrated earlier in this paper. The segregation is upset only by the inward migration of the pregnant females in the summer and early autumn. 
Ford has measured large numbers of embryo dogfish throughout the seasons, with very instructive results. In my judgment, he proves beyond doubt that the breeding season has definable limits, and that embryonic development is lengthy, taking about 25 months. Ford concludes that " from September onwards, specimens from 23 to $31 \mathrm{~cm}$., inclusive, satisfy the conditions for birth." These results are based on samples of dogfish landed at Plymouth. Owing to this protracted gestation period, " on any one day, the embryos are separable into two or three distinct size groups, according to the time of the year."

I have measured a certain number of the embryos found in the pregnant females fished by the George Bligh, and my results entirely confirm Ford's. The embryos fell into two distinct groups. One consisted of embryos between 4 and $7 \mathrm{~cm}$. in length, of which very few were measured, while the larger group consisted of embryos between 18 and $27 \mathrm{~cm}$., of which 233 were measured. In Table III are shown the length-frequencies of the embryos measured in the three regions.

\section{TABLE III}

Measurements of Embryo Dogfish, grouped by Regions.

\begin{tabular}{|c|c|c|c|}
\hline Length in $\mathrm{cm}$. & $\begin{array}{c}\text { Banks- } \\
\text { Westward. }\end{array}$ & Fastnet. & Galway-Bull. \\
\hline 18 & - & 1 & - \\
\hline 19 & - & 5 & 1 \\
\hline 20 & - & 9 & 4 \\
\hline 21 & 2 & 9 & 15 \\
\hline 22 & 8 & 19 & 17 \\
\hline 23 & 9 & 27 & 10 \\
\hline 24 & 13 & 10 & 24 \\
\hline 25 & 5 & 4 & 12 \\
\hline 26 & - & - & 5 \\
\hline 27 & - & - & 2 \\
\hline Totals & 37 & 84 & 90 \\
\hline Mean length & $23 \cdot 3$ & $22 \cdot 2$ & $23 \cdot 1$ \\
\hline
\end{tabular}

Few measurements are available from the Banks-Westward region, but the Galway-Bull embryos were plainly slightly more advanced than the Fastnet embryos, a fact which is wholly consistent with the suggestion that there is an earlier inward migration of the pregnant females in the Galway-Bull region. But the differences are slight, and it is evident that there would be no great lag in the time of birth of the young as between these three regions. 
The length distribution of the embryos in my samples agrees with Ford's August measurements.

In Figure 8 are drawn two curves. The pecked line shows the frequency at each centimetre length of the embryos of the larger group (all stations combined), the continuous line, the length-frequencies of the fish in the first mode of free-living young. The data are given in the Appendix, Table XVII. There is an overlap between the curves. Four fish, between 23 and $25 \mathrm{~cm}$. in length, which have been measured with the free-living young, can probably be neglected, for they were almost certainly squeezed from the parent by the violence of capture. Apart from these, the curve

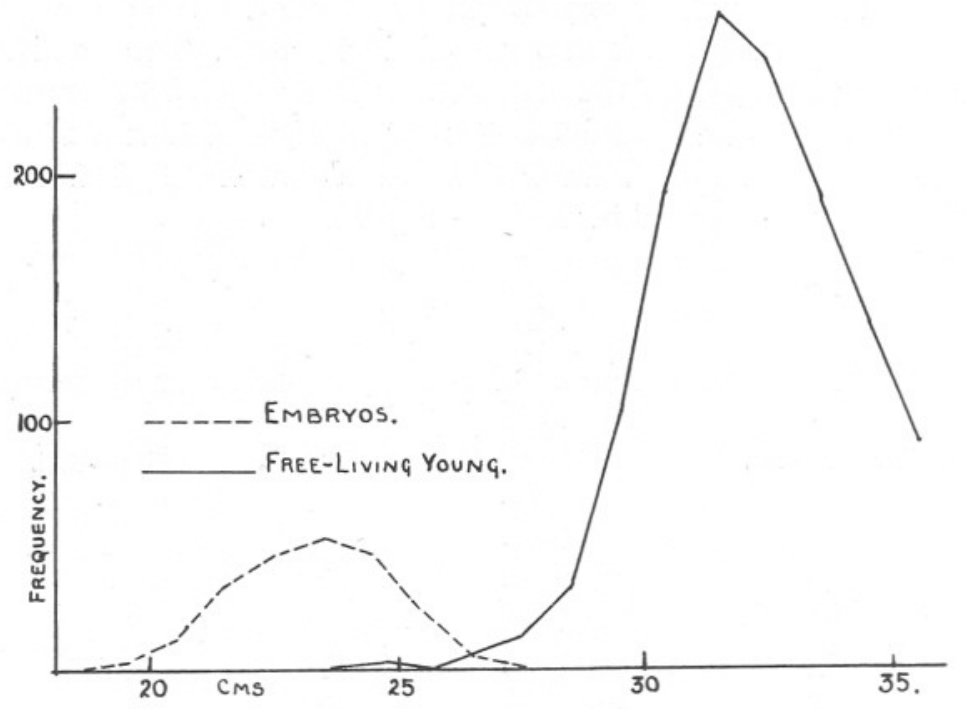

FIG. 8.-Frequency curves of embryos and free-living young of first mode. All stations, George Bligh, August, 1928. Data in Table XVII.

for unborn young ends, and that for free-living young commences, at $27 \mathrm{~cm}$.

It is curious that the modes of the curves for unborn and free-living young should be so widely separated. The modal lengths are roughly 23 and $32 \mathrm{~cm} .-9 \mathrm{~cm}$. apart. There are four possibilities.

(1) Growth may be very rapid immediately after birth.

(2) There may be a periodicity in the growth and birth of the embryos, such that the smallest free-living young belong to an earlier "wave."

(3) There may be a high mortality among the smaller newly-born fish. The resulting survival of the larger fish would effectively shift the modallength of the free-living young to the right.

(4). The birth of the young may not have yet begun, contrary to what 
has been suggested earlier in this paper. The free-living young may therefore belong to last year's brood, which has grown $9 \mathrm{~cm}$. in the interval.

Taking the last suggestion first, it is very unlikely that this is the correct explanation, because Ford finds that unborn embryos may reach a length of $31 \mathrm{~cm}$. ; secondly, because there is a continuity between the curves for unborn and free-living young, in Figure 8 , and $9 \mathrm{~cm}$. seems, on the face of it, to be too small an increment in a year ; and, finally, because, in many of the free-living young, the umbilical scar was still plainly visible, pointing to very recent birth.

While the third possibility given above is quite strong enough to be borne in mind, Ford's extensive measurements do not confirm the fourth suggestion, that there is a periodicity in the birth of the young.

When " condition" is dealt with later in this paper, it will be shown that there is a heavy loss in the condition of the liver as between unborn and free-living dogfish; in my view, growth immediately after birth is very rapid, and is carried out at the expense of the reserve materials stored in the liver of the embryo.

Summing up the results of the first section of this paper, the distribution of the dogfish at the time of the voyages is as follows: the males are present in shallower water than the females, and, owing to the strict segregation of the fish of both sexes according to size, and the smaller size attained by the males, in the deeper water females predominate. These big females are mostly pregnant, and make a migration from the deep to the shallow water to bear their young. The young are born at about $26 \mathrm{~cm}$., and, growing rapidly, move off to deeper water, the males already separating in shallower water than the females. Apart from the inward migration of the pregnant females, the dogfish seem strictly segregated according to size, in such a way that the larger fish are found in deeper water. The same segregation, according to size, was observed during the voyages of the Florence Brierley, in the early spring; it probably holds good at all times of the year.

The inward migration of the pregnant females, and the bearing of the young, seem to proceed from west to east, the process being most advanced to the West of Ireland, and least advanced in the latitude of Cornwall. This roughly-sketched picture will be compared, in the discussion, with Ford's notes on the dogfish landed at Plymouth market.

\section{CONDITION.}

A considerable number of weighing experiments were made on the Dogfish during the cruises of the George Bligh. The degree of accuracy, to be expected in weighings made at sea, is discussed in Section A of my 
Hake report (1930). Only larger dogfish, of more than $50 \mathrm{~cm}$., were dealt with in these weighing experiments.

The procedure was as follows: the fish was first measured, then the gut and gonads were removed, and the gutted fish weighed. The liver was then weighed, the stomach-contents, if any, noted, and, if the fish were a female, whether it were pregnant or not. Any embryos were removed and measured.

The data obtained were, length, sex, sexual condition, weight of liver, and weight of flesh. By "flesh" is here meant the gutted fish.

The data are set out in the Appendix, Table XVIII. The dogfish have

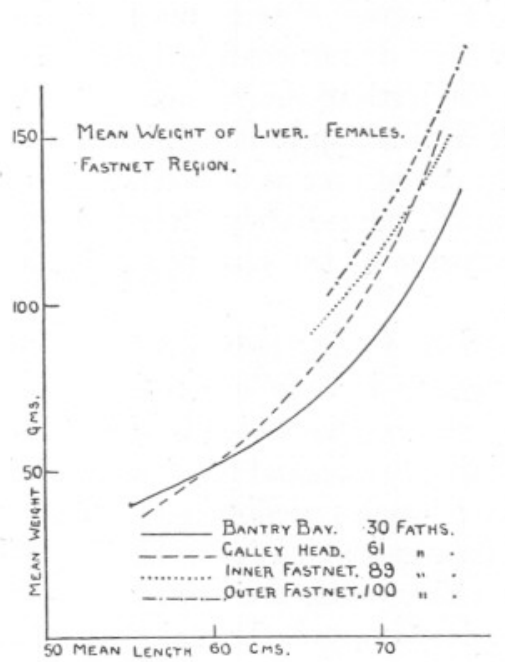

Fig. 9.

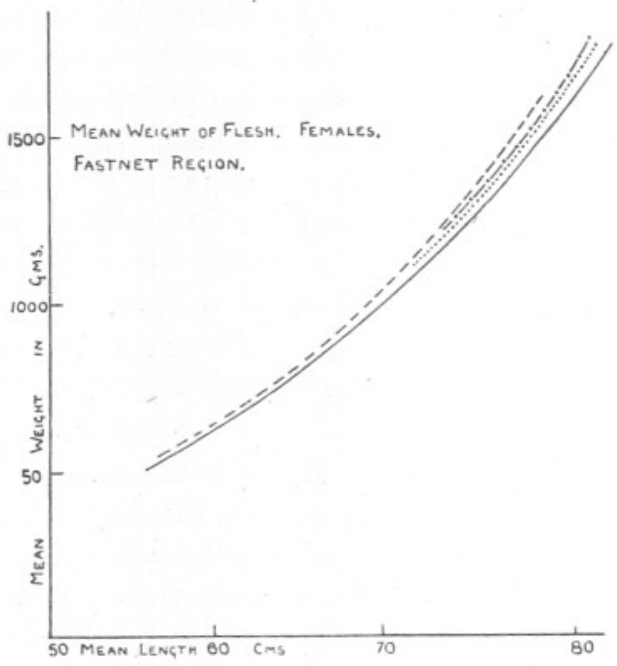

FIG. 10.

Frgs. 9 and 10.-Fastnet Region. Curves showing increase in mean weight of liver (Fig. 9), and flesh (Fig. 10), with increase of length, in immature and non-pregnant females. August, 1928. Data from Table XVIII.

been grouped into three classes, namely, males (without distinction into mature and immature), immature and non-pregnant females, and pregnant females. Each class is further sub-divided into $10-\mathrm{cm}$. groups, and for each 10 -cm. group the mean length, mean weight of liver, and mean weight of flesh has been calculated. Further, the value of the "coefficient of condition " $k$ has been calculated for each 10 -cm. category. This "coefficient $k$ " is given by the weight of the liver, or flesh, as the case may be, divided by the cube of the length of the fish. The value so obtained has been multiplied by 100 in order to eliminate two decimal places.

Selig Hecht (1913) published a note on the relation of weight to length in the dogfish Mustelus canis. He found that there was no sexual difference in the relation of weight to length in this fish. When weight was 
plotted against length, a curve drawn through the plotted points was found to have the form,

$$
y=a x^{3},
$$

where $y$ is the weight, $x$ the length, and $a$ a constant "whose value depends on the units used." He found that the variations in the value of $a$ with length are very slight, and therefore that " the relation of form to mass is clearly indicated by the young fish, and is continued with apparent mathematical accuracy as the fish increases in length and weight." Using his weight determinations, one can show that the value of the coefficient $k$ is highest in the 40-50-cm. group, and decreases until the 70-80-cm. group, after which there is a recovery in the $80-90-\mathrm{cm}$. group. But it is hardly feasible to compare Hecht's figures with mine, since he has not distinguished, in his means, between females and males, nor between pregnant and non-pregnant females.

An inspection of the data in the Appendix, Table XVIII, will show clearly that the coefficient $k$ is not a constant in the case of either the liver or the flesh, in my observation. In the liver it increases slowly with increase of length, a fact which will be given special emphasis in the discussion, and, in the flesh, as in Hecht's material, it decreases slowly with increase of length. But, for the present purpose, it may be considered constant over a short range of length, and therefore in comparing fish whose mean length varies only slightly from sample to sample. At the same time, this variation renders it risky to compare the mean value of $k$ in samples with a wide range of length. In this section, therefore, the data are divided into length-groups, and the means for the groups compared in the different samples.

First, however, the mean values for all the fish of each biological sub-group, at each station, may be examined. In Table IV below are set out the mean value of $k$ (liver) and $k$ (flesh) in the males, with the mean depth of the stations, and the number and mean length of the fish examined.

TABLE IV.

All Stations. Males. Mean Value of $k$ (Liver) and $k$ (Flesh).

$\begin{array}{lccccc}\begin{array}{c}\text { Station. } \\ \text { Bantry Bay }\end{array} & \begin{array}{c}\text { Mean } \\ \text { Depth. }\end{array} & \begin{array}{c}\text { Number } \\ \text { of fish. }\end{array} & \begin{array}{c}\text { Mean } \\ \text { length. }\end{array} & \begin{array}{c}\text { Mean } \\ \text { value } \\ \text { (liver). }\end{array} & \begin{array}{c}\text { Mean } \\ \text { value } \\ k \text { (llesh). }\end{array} \\ \text { Galley Head } & 30 & 40 & 67 \cdot 0 & \cdot 0229 & \cdot 280 \\ \text { "Station 18" } & 61 & 36 & 65 \cdot 3 & \cdot 0267 & \cdot 290 \\ \text { Between Banks } & 69 & 25 & 67 \cdot 8 & \cdot 0310 & \cdot 293 \\ \text { Cockburn Bank } & 69 & 25 & 61 \cdot 1 & \cdot 0238 & \cdot 259 \\ \text { Inner Fastnet } & 81 & 20 & 64 \cdot 5 & \cdot 0288 & \cdot 295 \\ \text { Outer Fastnet } & 89 & 25 & 69 \cdot 9 & \cdot 0327 & \cdot 294 \\ \text { Westward } & 100 & 30 & 69 \cdot 7 & \cdot 0339 & \cdot 289 \\ & 105 & 6 & 71 \cdot 2 & \cdot 0349 & \cdot 292\end{array}$


This table shows clearly that the mean value of $k$ (liver) increases with increase of depth. The only discrepancies are the Banks and Cockburn Bank samples, which give lower values than the other stations of comparable depth. But the table shows that these fish also had a lower mean length than those of these other stations. The mean values for the flesh do not show such a definite relation with depth.

In Table V, a similar comparison is made for immature and nonpregnant females.

\section{TABLe V.}

All Stations. Immature and Non-Pregnant Females. Mean Value of $k$ (Liver) and $k$ (Flesh).

$\begin{array}{lccccc}\quad \text { Station. } & \begin{array}{c}\text { Mean } \\ \text { Depth. }\end{array} & \begin{array}{c}\text { Number } \\ \text { of fish. }\end{array} & \begin{array}{c}\text { Mean } \\ \text { length. }\end{array} & \begin{array}{c}\text { Mean } \\ \text { value } \\ \text { (liver). }\end{array} & \begin{array}{c}\text { Mean } \\ \text { value } \\ \text { (flesh). }\end{array} \\ \text { Bantry Bay } & 30 & 44 & 64 \cdot 2 & \cdot 0263 & \cdot 289 \\ \text { Galley Head } & 61 & 51 & 66 \cdot 8 & \cdot 0298 & \cdot 306 \\ \text { "Station 18" } & 69 & 28 & 67 \cdot 4 & \cdot 0325 & \cdot 305 \\ \text { Between Banks } & 69 & 20 & 57 \cdot 9 & \cdot 0245 & \cdot 274 \\ \text { Cockburn Bank } & 81 & 19 & 63 \cdot 3 & \cdot 0252 & \cdot 295 \\ \text { Innet Fastnet } & 89 & 32 & 70 \cdot 3 & \cdot 0352 & \cdot 303 \\ \text { Outer Fastnet } & 100 & 26 & 73 \cdot 5 & \cdot 0407 & \cdot 298 \\ \text { Westward } & 105 & 8 & 74 \cdot 4 & \cdot 0372 & \cdot 308 \\ \text { Bull } & 130 & 15 & 75 \cdot 6 & \cdot 0409 & \cdot 314\end{array}$

In immature and non-pregnant females also, there is a very well marked increase in the value of the coefficient $k$ (liver) with increase of depth. As in the males, the stations in the Banks-Westward group give lower values than the other stations of a comparable depth. The mean values for $k$ (flesh) do not show the same relation to depth.

In every case, the mean value for $k$ (flesh) is greater in the female than in the male, and in every case except the Cockburn Bank station the value of $k$ (liver) is greater in the female than in the male.

Finally, in Table VI are compared the mean values for $k$ (liver) and $k$ (flesh) in pregnant females.

TABLE VI.

All Stations. Pregnant Females. Mean Value of $k$ (Liver) AND $k$ (FLESH).

\begin{tabular}{lccccc}
\multicolumn{1}{c}{ Station. } & $\begin{array}{c}\text { Mean } \\
\text { Depth. }\end{array}$ & $\begin{array}{c}\text { Number } \\
\text { of fish. }\end{array}$ & $\begin{array}{c}\text { Mean } \\
\text { length. }\end{array}$ & $\begin{array}{c}\text { Mean } \\
\text { value } \\
k \text { (liver). }\end{array}$ & $\begin{array}{c}\text { Mean } \\
\text { value } \\
k \text { (flesh). }\end{array}$ \\
Inside Aran Islands & 21 & 8 & $87 \cdot 9$ & $\cdot 0222$ & $\cdot 306$ \\
Bantry Bay & 30 & 12 & $85 \cdot 3$ & $\cdot 0227$ & $\cdot 302$ \\
Galway Bay & 55 & 33 & $85 \cdot 5$ & $\cdot 0263$ & $\cdot 305$ \\
Galley Head & 61 & 9 & $83 \cdot 3$ & $\cdot 0334$ & $\cdot 337$ \\
Westward & 105 & 13 & $82 \cdot 0$ & $\cdot 0351$ & $\cdot 322$
\end{tabular}


It is clear, from Table VI, that in pregnant females, as in the other two biological sub-groups of the dogfish, there is a very well marked increase in the value of $k$ (liver), with increase of depth, and that this increase is not shown, at least so distinctly, in the values of $k$ (flesh).

In the Bantry Bay and Westward samples, the mean value for $k$ (liver) is distinctly less in pregnant than in non-pregnant females, that for $k$ (flesh) greater. The latter is at first sight understandable, since the mean length of the pregnant females is much greater than that of the non-pregnant females. Later in this section, it will be shown that, even when the effect of a different mean length is minimised, the liver of the pregnant female is generally lighter, the flesh generally heavier, than in non-pregnant females.

Tables IV, V, and VI show that, in many of the stations, the sampling is fairly adequate, at others, where very few dogfish were found, it is, of course, less satisfactory. But since the values for the coefficient $k$ are not constant with increase of length, it will be necessary to confirm the conclusions drawn from Tables IV, V, and VI, by an examination of the fish divided into 10-cm. categories.

The 10-cm. categories into which the data have been grouped are $50-59 \mathrm{~cm} ., 60-69 \mathrm{~cm}$., etc., the number of weighings from which the mean has been calculated varies considerably from sample to sample, and the reliability of the mean varies accordingly. But, in the Fastnet group of stations, the sampling is satisfactory, and one can regard the results with some confidence. The stations in the Fastnet region will therefore be discussed first, and a comparison will then be made between the Fastnet group of stations and the remaining two groups of stations.

In Figure 9 four curves are drawn. Each curve represents the increase in mean weight of the liver, with increase of length, in immature and nonpregnant female dogfish. The four curves refer to the four stations of the Fastnet group. They are distinguished by conventional signs explained in the figure. An inspection of the curves will show that they arrange themselves in such a way that the lowest curve is that for the Bantry Bay sample, the highest, the Outer Fastnet sample, in other words, the mean weight of the liver increases with increase of depth. This may also be demonstrated by using the coefficient $k$, as in the Table below, which has been extracted from Table XVIII.

TABLE VII.

Fastnet Group. Immature and Non-Pregnant Females. Liver.

\begin{tabular}{|c|c|c|c|c|c|c|c|}
\hline \multirow{3}{*}{$\begin{array}{c}\text { Station. } \\
\text { Bantry Bay }\end{array}$} & \multirow[b]{2}{*}{$\begin{array}{l}\text { Depth. } \\
\text { Fathom. }\end{array}$} & \multicolumn{2}{|c|}{$50-59 \mathrm{~cm}$. } & \multicolumn{2}{|c|}{$60-69 \mathrm{~cm}$} & \multicolumn{2}{|c|}{$70-79 \mathrm{~cm}}$. \\
\hline & & $\begin{array}{l}\text { Mean } \\
\text { length. }\end{array}$ & $\begin{array}{l}\text { Mean value } \\
\text { of } k \text { (liver). }\end{array}$ & $\begin{array}{l}\text { Mean } \\
\text { length. }\end{array}$ & $\begin{array}{l}\text { Mean value } \\
\text { of } k \text { (liver). }\end{array}$ & $\begin{array}{l}\text { Mean } \\
\text { length. }\end{array}$ & $\begin{array}{l}\text { Mean value } \\
\text { of } k \text { (liver). }\end{array}$ \\
\hline & 30 & $55 \cdot 0$ & .0234 & $64 \cdot 7$ & .0250 & $74 \cdot 3$ & .0310 \\
\hline Galley Head & 61 & $55 \cdot 5$ & .0216 & $64 \cdot 6$ & $\cdot 0267$ & $72 \cdot 3$ & .0351 \\
\hline Inner Fastnet & 89 & $58 \cdot 5^{*}$ & $.0238^{*}$ & $65 \cdot 8$ & $\cdot 0321$ & $73 \cdot 1$ & .0355 \\
\hline Outer Fastnet & 100 & - & - & $67 \cdot 3$ & $\cdot 0345$ & $75 \cdot 2$ & $\cdot 0413$ \\
\hline
\end{tabular}


In all three length-categories dealt with in the table, the value of $k$ (liver) increases with increase of depth ; the only discrepancy is the value of the mean for $50-59 \mathrm{~cm}$. in the Galley Head sample.

In Figure 10 are drawn the four corresponding curves for the mean weight of flesh in the stations of the Fastnet group. The flesh, like the liver, is seen to show a tendency towards an increase in mean weight with increase of depth, though this is not so well-marked as in the liver. The curve for Galley Head, in particular, is high, and the large fish at this station were heavier than the fish of corresponding size at either the Inner or the Outer Fastnet. In the table below are set forth the values of the coefficient $k$ (flesh).

\section{TABLE VIII.}

Fastnet Group. Immature and Non-Pregnant Females. Flesh.

\begin{tabular}{|c|c|c|c|c|c|c|c|}
\hline \multirow{2}{*}{ Station. } & \multirow[b]{2}{*}{$\begin{array}{l}\text { Depth. } \\
\text { Fathom. }\end{array}$} & \multicolumn{2}{|c|}{$50-59 \mathrm{~cm}}$. & \multicolumn{2}{|c|}{$60-69 \mathrm{~cm}$. } & \multicolumn{2}{|c|}{$70-79 \mathrm{~cm}}$. \\
\hline & & $\begin{array}{l}\text { Mean } \\
\text { length. }\end{array}$ & $\begin{array}{l}\text { Mean value } \\
\text { of } k \text { (flesh) }\end{array}$ & $\begin{array}{l}\text { Mean } \\
\text { length. }\end{array}$ & $\begin{array}{l}\text { Mean value } \\
\text { of } k \text { (flesh) }\end{array}$ & $\begin{array}{l}\text { Mean } \\
\text { length. }\end{array}$ & $\begin{array}{l}\text { Mean value } \\
\text { of } k \text { (flesh). }\end{array}$ \\
\hline Bantry Bay & 30 & $55 \cdot 0$ & $\begin{array}{l}.289 \\
.281\end{array}$ & $64 \cdot 7$ & .289 & $74 \cdot 3$ & .290 \\
\hline Galley Head & 61 & $55 \cdot 5$ & .295 & $64 \cdot 6$ & $\cdot 297$ & $72 \cdot 3$ & $\cdot 325$ \\
\hline Inner Fastnet & 89 & $58 \cdot 5$ & $\cdot 313^{*}$ & $65 \cdot 8$ & $\cdot 302$ & $73 \cdot 1$ & $\cdot 299$ \\
\hline Outer Fastnet & 100 & - & - & $67 \cdot 3$ & $\cdot 287$ & $75 \cdot 2$ & $\cdot 301$ \\
\hline
\end{tabular}

The relation between depth and "condition" in the flesh can still be traced, but there is a discrepancy in the $60-69-\mathrm{cm}$. category, where the Outer Fastnet value is lower than the Inner Fastnet value, and in the 70-79-cm. category, where the Galley Head value is very high.

In Figure 11 are set forth the curves for increase in weight of the liver, with increase of length, in male dogfish in the four Fastnet stations. These curves show, even more clearly than those for the females, the increase in mean weight of the liver with increase of depth. There is one curious difference between males and females, however; as Figure 11 shows, the curve for increase of weight with increase of length does not continue to rise, but falls away from the $60-69-\mathrm{cm}$. category to the 70 79-cm. category. This falling-off in the condition of the larger (and older) males may also be observed in the variations in the value of the coefficient $k$ (liver).

\section{TABLE IX.}

Fastnet Group. Males. Liver.

\begin{tabular}{|c|c|c|c|c|c|c|c|}
\hline & & & & & & & \\
\hline Stati & $\begin{array}{l}\text { Depth. } \\
\text { Fathom, }\end{array}$ & $\begin{array}{l}\text { Mean } \\
\text { length. }\end{array}$ & $\begin{array}{l}\text { Mean value } \\
\text { of } k \text { (liver). }\end{array}$ & $\begin{array}{l}\text { Mean } \\
\text { length. }\end{array}$ & $\begin{array}{l}\text { Mean value } \\
\text { of } k \text { (liver). }\end{array}$ & $\begin{array}{l}\text { Mean } \\
\text { length. }\end{array}$ & $\begin{array}{l}\text { Mean valu } \\
\text { of } k \text { (flesh) }\end{array}$ \\
\hline ntro $\mathrm{B}$. & 30 & $57 \cdot 2$ & .0179 & 66.5 & .0240 & $72 \cdot 8$ & .0235 \\
\hline & 61 & 56.8 & .0221 & $66 \cdot 0$ & .0278 & & .0275 \\
\hline er Fastnet & 89 & - & - & 66 & .0327 & $72 \cdot 3$ & .0326 \\
\hline ater Fastnet & 100 & - & - & $67 \cdot 5$ & .0317 & $72 \cdot 2$ & .0365 \\
\hline
\end{tabular}


There is only one exception to the otherwise perfectly demonstrated increase in mean weight with increase in depth ; this is in the 60-69-cm. category, where it is seen that the Outer Fastnet sample gives a low value of $k$ (liver).

When the curves for increase of weight in the flesh, with increase of length, are drawn, an increase of mean weight with increase of depth is shown more definitely than in the female, though not nearly so well as

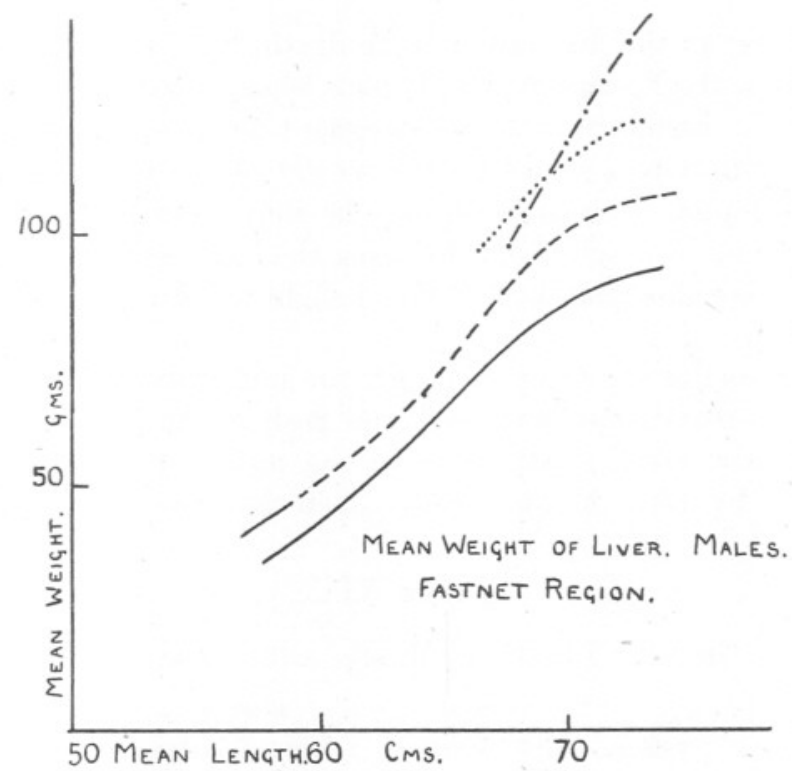

Fig. 11.-Fastnet Region. Curves showing increase in mean weight of liver, with increase of length, in male dogfish. George Bligh, August, 1928. Data from Table XVIII.

the liver in either sex. These curves are not shown in the text, since it is plain that the flesh does not share, to an extent comparable with the liver, in the curious agreement between depth and condition to which this section draws attention. The values of the coefficient $k$ will be sufficient to indicate the variations in the condition of the flesh, with regard to depth.

When these variations, in the case of the males, are examined, as in the table below, it is seen that the Inner and Outer Fastnet samples, in the 60-69-cm. category, have lower values than the Galley Head sample, while, in the 70-79-cm. category, the Outer Fastnet value is lower than the Inner Fastnet value. 


\section{TABLE X.}

Fastnet Group. Males. Flesh.

\begin{tabular}{|c|c|c|c|c|c|c|c|}
\hline \multirow[b]{2}{*}{ Station. } & \multirow[b]{2}{*}{$\begin{array}{l}\text { Depth. } \\
\text { Fathom. }\end{array}$} & \multicolumn{2}{|c|}{$50-59 \mathrm{~cm}$. } & \multicolumn{2}{|c|}{$60-69 \mathrm{~cm}$. } & \multicolumn{2}{|c|}{$70-79 \mathrm{~cm}$. } \\
\hline & & $\begin{array}{l}\text { Mean } \\
\text { length. }\end{array}$ & Mean value & Mean & Mean value & Mean & Mean value \\
\hline Bantry Bay & 30 & $57 \cdot 2$ & .283 & $66 \cdot 5$ & $\begin{array}{c}\text { or } k \text { (nesh). } \\
.281\end{array}$ & $\begin{array}{l}\text { length. } \\
72 \cdot 8\end{array}$ & $\begin{array}{l}\text { t } k \text { (flesn). } \\
.276\end{array}$ \\
\hline Galley Head & 61 & $56 \cdot 8$ & $\cdot 287$ & $66 \cdot 0$ & .292 & $72 \cdot 7$ & .285 \\
\hline Inner Fastnet & 89 & - & - & $66 \cdot 4$ & $\cdot 287$ & $72 \cdot 3$ & $\cdot 298$ \\
\hline Outer Fastnet & 100 & - & - & $67 \cdot 5$ & $\cdot 290$ & $72 \cdot 2$ & $\cdot 287$ \\
\hline
\end{tabular}

In summing up the deductions to be drawn from this examination of the data from the Fastnet region, it may be said that the liver, in both males, and in immature and non-pregnant females, shows a striking agreement with depth, such that the weight of the liver increases with increase of depth. This increase may be shown both by an inspection of the actual mean weights, and by using the length-weight coefficient $k$. The flesh shows this relation to a much slighter degree, especially in the deeper water.

When the males are compared with the immature and non-pregnant females, it is found that both liver and flesh in the female are slightly heavier, at any given depth, than in the male. This may be shown conveniently by using the coefficient $k$, as in the table below.

\section{Table XIa.}

Fastnet Group. Liver in Males and females Compared.

\begin{tabular}{|c|c|c|c|c|c|c|c|c|}
\hline \multirow{3}{*}{$\begin{array}{c}\text { Station. } \\
\text { Bantry Bay }\end{array}$} & & \multirow[b]{2}{*}{$\begin{array}{l}\text { Depth. } \\
\text { Fathom. }\end{array}$} & \multicolumn{2}{|c|}{$50-59 \mathrm{~cm}}$. & \multicolumn{2}{|c|}{ 60-69 cm. } & \multicolumn{2}{|c|}{$70-79 \mathrm{~cm}$. } \\
\hline & & & $\begin{array}{l}\text { Mean } \\
\text { length. }\end{array}$ & $\begin{array}{l}\text { Mean value } \\
\text { of } k \text { (liver). }\end{array}$ & $\begin{array}{l}\text { Mean } \\
\text { length. }\end{array}$ & $\begin{array}{l}\text { Mean value } \\
\text { of } k \text { (liver). }\end{array}$ & $\begin{array}{l}\text { Mean } \\
\text { length. }\end{array}$ & $\begin{array}{l}\text { Mean value } \\
\text { of } k \text { (liver). }\end{array}$ \\
\hline & tే & 30 & $57 \cdot 2$ & .0179 & $66 \cdot 5$ & .0240 & $72 \cdot 8$ & .0235 \\
\hline & 7 & & $55 \cdot 0$ & .0234 & $64 \cdot 7$ & $\cdot 0250$ & $74 \cdot 3$ & .0310 \\
\hline Galley Head & to & 61 & $56 \cdot 8$ & $\begin{array}{r}0221 \\
0\end{array}$ & $\cdot 0$ & .0278 & $72 \cdot 7$ & 02 \\
\hline & & & $55 \%$ & $\cdot 02$ & $64 \cdot($ & .0267 & 72 & $\cdot 0351$ \\
\hline & ơ & 80 & & - & & .0321 & $73 \cdot 1$ & $\cdot 0355$ \\
\hline Ou & $0^{6}$ & 100 & $\ldots$ & - & $\begin{array}{c}67 \cdot 5 \\
67 \cdot 3\end{array}$ & $\begin{array}{l}\cdot 0317 \\
\cdot 0345\end{array}$ & ${ }_{75 \cdot 2}^{72 \cdot 2}$ & ${ }^{.0413^{.0365}}$ \\
\hline
\end{tabular}

Fastnet Group. Flesh in Males and Females Compared.

\begin{tabular}{|c|c|c|c|c|c|c|c|c|}
\hline Bantry Bay & $0^{t}$ & 30 & $57 \cdot 2$ & $\cdot 283$ & $66 \cdot 5$ & .281 & $72 \cdot 8$ & \\
\hline & o & & $55 \cdot 0$ & $\cdot 289$ & $64 \cdot 7$ & $\cdot 289$ & $74 \cdot 3$ & $\cdot 290$ \\
\hline Galley Head & & 61 & $\begin{array}{l}56 \cdot 8 \\
55 \cdot 5\end{array}$ & $\cdot 295^{\cdot 287}$ & $\begin{array}{l}66 \cdot 0 \\
64 \cdot 6\end{array}$ & $\cdot 297^{-292}$ & $\begin{array}{c}72 \cdot 7 \\
72 \cdot 3\end{array}$ & \\
\hline Inner Fastnet & & 89 & - & - & $66 \cdot 4$ & 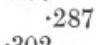 & 72 & \\
\hline Outer Fastnet & o & 100 & - & & $\begin{array}{l}65 \cdot 8 \\
67 \cdot 5 \\
67 \cdot 3\end{array}$ & $\begin{array}{l}\cdot 302 \\
\cdot 290 \\
\cdot 287\end{array}$ & $\begin{array}{c}73 \cdot 1 \\
72 \cdot 2 \\
75 \cdot 2\end{array}$ & \\
\hline
\end{tabular}

The exceptions to the above, in the case of the liver, are in the 50-59-cm. and $60-69-\mathrm{cm}$. category in the Galley Head sample, and the 60-69-cm. in the Inner Fastnet sample. In the case of the flesh, the only exceptions are 
the Outer Fastnet values at $60-69 \mathrm{~cm}$., in which the male is slightly heavier than the female. The table justifies one, in my opinion, in stating that the liver and flesh of the female dogfish tend to be heavier, at any given depth, than the liver and flesh of the male.

Hitherto, we have only considered immature and non-pregnant females. In the Fastnet group of stations sufficient numbers of pregnant females to be worth discussing were only found at the Bantry Bay and Galley Head stations. As Table VI shows, pregnant females in the Bantry Bay sample (30 fathoms) had both liver and flesh considerably lighter than in the Galley Head sample ( 61 fathoms). In this series of stations, therefore, pregnant females show the same increase in mean weight, with increase of depth, shown by immature and non-pregnant females, and by males.

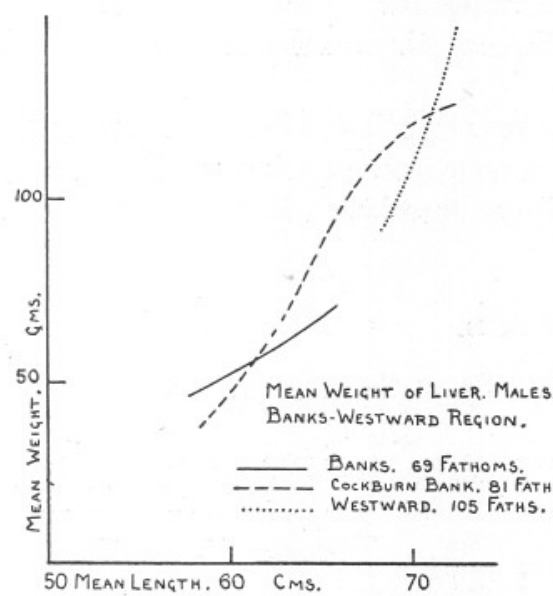

Fig. 12.

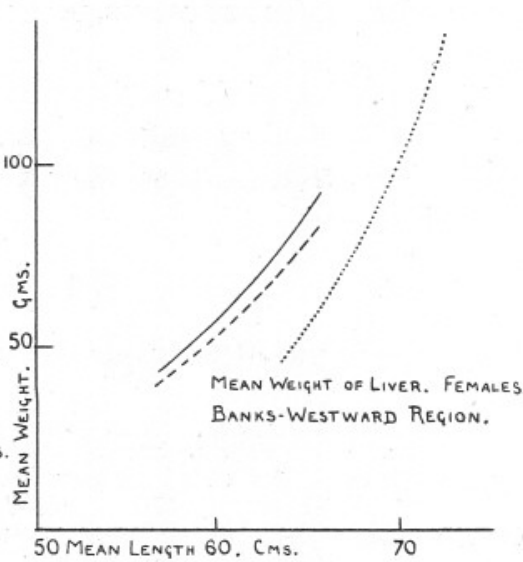

FIG. 13.

Figs. 12 and 13.-Banks-Westward Region. Curves showing increase in mean weight of liver, with increase of length, in male (Fig. 12) and female (Fig. 13) dogfish. George Bligh, August, 1928. Data from Table XVIII.

These results, based on the well-sampled Fastnet group of stations, confirm, by an inspection of the $10-\mathrm{cm}$. categories, the conclusions, based on the mean values of all specimens, drawn from Tables IV and V; they may now be compared with the Banks-Westward, and Galway-Bull groups of stations.

A comparison of the mean weights of liver and flesh at the three stations in the Banks-Westward group of stations is difficult, because, as we have seen in Section I, larger fish, especially females, are rare or absent in the Banks and Cockburn Bank samples, while smaller fish are lacking in the Westward sample.

In Figure 12 are drawn three curves, distinguished by conventional signs, representing the increase of mean weight of the liver of male dogfish, 
with increase of length, in the three stations of the Banks-Westward series. The curves do not lie parallel to one another, and do not show the same increase in mean weight, with increase of depth, shown by the fish in the Fastnet region. The curves for the shallowest (Banks), and the deepest station (Westward), are continuous with each other, while the curve for the Cockburn Bank sample cuts both, showing the same fallingoff at the higher-length category shown by the males in the Fastnet stations.

In Figure 13 the corresponding three curves for the females are drawn. Here there is a definite relation between mean weight and depth, but it is the reverse from what was found in the Fastnet region. Here, the mean weight of the liver decreases with increase of depth.

In the table below are set out the values for the coefficient $k$ in both liver and flesh, for both sexes, in the three stations of the Banks-Westward region.

An inspection of this table shows that the relation between depth and condition in the liver tends to be an inverse one, especially in the female, whereas the flesh tends to show a direct correlation between depth and condition.

TABLE XIB.

Banks-Westward Group. Both Sexes. Liver.

\begin{tabular}{|c|c|c|c|c|c|c|c|}
\hline & & & 0 & & & & \\
\hline & $\begin{array}{l}\text { Depth. } \\
\text { Fathom. }\end{array}$ & $\begin{array}{l}\text { Mean } \\
\text { length. }\end{array}$ & $\begin{array}{l}\text { Mean va } \\
\text { of } k \text { (liv }\end{array}$ & $\begin{array}{l}\text { Mean } \\
\text { length. }\end{array}$ & $\begin{array}{l}\text { Mean va } \\
\text { of } k \text { (liv }\end{array}$ & $\begin{array}{l}\text { Mean } \\
\text { length. }\end{array}$ & $\begin{array}{l}\text { Mean value } \\
\text { of } k \text { (liver). }\end{array}$ \\
\hline nks & $\begin{array}{ll}\sigma^{*} & 69\end{array}$ & $58 \cdot 0$ & 0238 & $64 \cdot 6$ & $\cdot 0237$ & - & - \\
\hline & & $57 \cdot 1$ & $\cdot 0237$ & $65 \cdot 0$ & $\cdot 0317$ & - & - \\
\hline Bank & 81 & $58 \cdot 3$ & 0187 & $64 \cdot 8$ & 0307 & $71 \cdot 2$ & .0343 \\
\hline estward & ơ 105 & ${ }^{56 \cdot 5}-$ & ${ }_{-}^{0218}$ & $\begin{array}{c}63 \cdot 9 \\
68 \cdot 5 \\
63 \cdot 5\end{array}$ & $\begin{array}{c}.0279 \\
.0288 \\
.0177\end{array}$ & $\begin{array}{c}76 \cdot 0 \\
72 \cdot 5 \\
76 \cdot 5\end{array}$ & $\begin{array}{c}.0381 \\
.0454\end{array}$ \\
\hline
\end{tabular}

Banks-Westward Group. Both Sexes. Flesh.

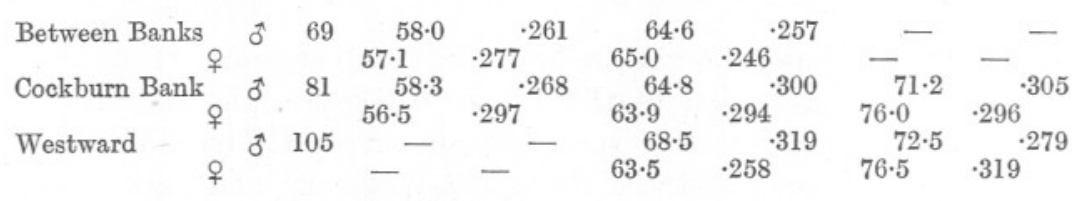

When the values of $k$ (liver) and $k$ (flesh) in males and females are compared, as in the table above, it is apparent that, in some cases, the liver and flesh are heavier in the male than in the female, while, in other cases, the reverse is true. Thus, the male liver is lighter than the female liver in the Cockburn Bank sample at 50-59 cm., in the Banks sample at 60$69 \mathrm{~cm}$., and in the Westward sample at 70-79 $\mathrm{cm}$. The male flesh is lighter than the female flesh in the Banks, and Cockburn Bank samples 
at $50-59 \mathrm{~cm}$., in none of the samples at $60-69 \mathrm{~cm}$., and in the Westward sample at $70-79 \mathrm{~cm}$.

Thus, neither the increase in mean weight of the liver, with increase of depth, nor the greater mean weights of liver and flesh in the female, are definitely confirmed by the Banks-Westward samples, and, though the data available from these are inadequate for a comparison with the Fastnet samples, they must be borne in mind, especially the reversal of the depthweight relation in the females in the Banks-Westward region.

In the Galway-Bull group, a profitable comparison is only possible as between the pregnant females, since males of a size greater than $50 \mathrm{~cm}$. were practically absent from all three stations, and immature and nonpregnant females were absent from the Galway Bay sample, and from the sample from very shallow water inside the Aran Islands. It may be pointed out, however, that, as Table $\mathrm{V}$ shows, immature females have a very high value of $k$ (liver) (.0409) in the Bull sample (130 fathoms). This is also true of the flesh.

Comparing the pregnant females in Table VI from the station inside the Aran Islands (21 fathoms) with those from the Galway Bay station (55 fathoms), it can be seen that the flesh of the pregnant females at these two stations is approximately equal, the liver distinctly lighter in the shallower station.

It should be interesting to compare the mean weight and the mean value of the coefficient $k$, in pregnant females from the Galway-Bull groups of stations, with the Fastnet and Banks-Westward groups of stations, because it was suggested, in the first section of this paper, from an examination of the length-distributions, that the three groups of stations showed, in the order named, a progressively later stage in the birth of the young. The comparison may be made by an inspection of Table VI.

The lowest value of $k$, in the flesh, is found in the Bantry Bay sample. The very shallow water station inside the Aran Islands, and the Galway Bay station, have values which, though equal to, or higher than those for Bantry Bay, are considerably less than those for Galley Head, and the Westward ground. The last-named stations have liver and flesh showing contrary tendencies. The liver in the Westward sample is considerably heavier than the liver in the Galley Head sample, but the flesh in the Westward sample is slightly lighter than the flesh in the Galley Head sample. But before the data in this table can be examined for confirmation, or the reverse, as to whether the process of parturition of the year's brood of young progresses from west to east, as suggested earlier in this paper, the liver and flesh in pregnant and non-pregnant females must be compared.

A direct comparison is possible at only two stations, namely, Galley Head, and the Westward, since the fish compared must be of approximately equal length. 
In Table XIIA, below, are set out the mean weights, and the mean values of the coefficient $k$, in both liver and flesh, at these two stations, in the 80-89-cm. category.

\section{TABLE XIIA.}

Comparison of Liver and Flesh in Pregnant and NonPregnant Females. 80-89 cm.

\begin{tabular}{|c|c|c|c|c|c|c|}
\hline $\begin{array}{l}\text { Station. } \\
\text { Galley Head, pregnant } \\
\text { non-pregnant }\end{array}$ & $\begin{array}{l}\text { Depth. } \\
61\end{array}$ & $\begin{array}{c}\text { Mean } \\
\text { length. } \\
83 \cdot 3 \\
81 \cdot 7\end{array}$ & $\begin{array}{c}\text { Mean } \\
\text { weight } \\
\text { (liver). } \\
192 \\
233\end{array}$ & $\begin{array}{c}\text { Mean } \\
\text { value } \\
k \text { (liver). } \\
\cdot 0334 \\
.0428\end{array}$ & $\begin{array}{c}\text { Mean } \\
\text { weight } \\
\text { (flesh). } \\
1950 \\
1730\end{array}$ & $\begin{array}{c}\text { Mean } \\
\text { value } \\
k \text { (flesh) } \\
\cdot 337 \\
\cdot 318\end{array}$ \\
\hline & \multicolumn{2}{|c|}{ Difference } & -41 & -.0094 & +220 & $+\cdot 019$ \\
\hline \multirow[t]{2}{*}{$\begin{array}{r}\text { Westward, pregnant } \\
\text { non-pregnant }\end{array}$} & 105 & $\begin{array}{l}84 \cdot 5 \\
81 \cdot 0\end{array}$ & $\begin{array}{l}215 \\
215\end{array}$ & $\begin{array}{l}.0353 \\
.0403\end{array}$ & $\begin{array}{l}1960 \\
1800\end{array}$ & $\begin{array}{l}\cdot 325 \\
\cdot 339\end{array}$ \\
\hline & \multicolumn{2}{|c|}{ Difference } & 0 & -.0050 & +160 & -.014 \\
\hline
\end{tabular}

Both stations agree in the following points: The liver of the pregnant female is lighter, having regard to the mean lengths, than that of the nonpregnant female, and the flesh of the pregnant female is heavier than that of the non-pregnant female. In the 70-79-cm. group, in the Westward sample, the liver is considerably lighter in the pregnant than in the nonpregnant fish, but the flesh is also lighter. As Table XVIII in the Appendix shows, the value of $k$ (liver) is always low in pregnant females.

A voyage made on the Fleetwood steam-trawler Kumu in October, 1928, to the Inishtrahull grounds, off the north-west of Ireland, gave me a good opportunity to compare the mean weight of liver and flesh as between non-pregnant females, females early in pregnancy, and females late in pregnancy. As in Ford's November samples at Plymouth, there were three groups of embryos at this time. There were large embryos, from 22 to $27 \mathrm{~cm}$., smaller embryos from 7 to $10 \mathrm{~cm}$., and, finally, very young embryos still enclosed in their horny capsules. The female dogfish were divided into three classes, namely, non-pregnant females, females containing horny capsules, and females containing embryos of the two larger sizes. The length-category $80-89 \mathrm{~cm}$. was chosen for the comparison, which is made in the table below.

TABLE XIIB.

Inishtrahull. October, 1928. Comparison of Condition in Females 80-89 CM.

$\begin{array}{lccccc}\text { Female category. } & \begin{array}{c}\text { Mean } \\ \text { length. }\end{array} & \begin{array}{c}\text { Mean wt. } \\ \text { of liver. }\end{array} & \begin{array}{c}\text { Mean value } \\ \text { of } k \text { (liver). }\end{array} & \begin{array}{c}\text { Mean wt. } \\ \text { of flesh. }\end{array} & \begin{array}{c}\text { Mean value } \\ \text { of } k \text { (flesh). }\end{array} \\ \text { 1. Non-pregnant } & 81 \cdot 9 & 238 & \cdot 0433 & 1625 & \cdot 296 \\ \text { 2. Pregnant (Capsules) } & 83 \cdot 8 & 232 & \cdot 0391 & 1810 & \cdot 308 \\ \text { 3. Pregnant (Embryos) } & 86 \cdot 0 & 167 & \cdot 0261 & 1945 & \cdot 305\end{array}$


In comparing the non-pregnant females (row 1) with the pregnant females containing embryos (row 3), exactly the same relation between the two classes is shown, as has been described in the Galley Head and Westward samples. The liver is considerably lighter in pregnant than in non-pregnant females, the flesh decidedly heavier.

In the pregnant females containing capsules, that is, in an early state of pregnancy, the liver is only slightly lighter than the liver of nonpregnant females, but the flesh is already decidedly heavier. Thus one may suggest that the liver is gradually drained of its resources during pregnancy ; but the increase of weight of the flesh may be due to a development of the musculature to cope with the extra work involved during the long period of pregnancy.

Returning to Table VI, it is seen that, although the Bantry Bay sample has the lowest $k$ value of liver and flesh, the two stations in the Galway-Bull group have lower combined $k$ values of liver and flesh than the two stations in the Fastnet group, and may therefore probably show a more advanced state of pregnancy in the females, subject to the qualification set out in the following paragraph.

On the other hand, Table XIIA also shows that the difference between the mean weights of the liver and flesh in pregnant and non-pregnant females is much less in the Westward than in the Galley Head sample. In the dogfish samples obtained on the voyages of the Florence Brierley, there was no difference between the mean values for $k$ (liver) in pregnant and nonpregnant females. The mean value of $k$ (liver) in the pregnant females was $\cdot 042$, identical with that for the non-pregnant females. These fish were all taken in very deep water, and it may therefore be possible that the greater part of the weight of the liver lost by the pregnant females may be lost during the actual inward migration from deep to shallow water.

During the 1928 cruise of the George Bligh I made a note that the liver of the embryo dogfish appeared remarkably creamy and full, almost filling the body-cavity. During the 1929 cruise, I was able to make some experiments to test this.

The modal length of the embryos found in Galway Bay was $21 \mathrm{~cm}$., and the first mode of free-living young was at $29 \mathrm{~cm}$. The value of $k$ (liver) in the embryos at the modal length (mean of 9 specimens) was $\cdot 033$, in the free-living young (mean of 15 specimens) $\cdot 025$. Thus, from an investigation of an admittedly small number of fish, the conclusion seems to be confirmed that the liver in the embryo is very much heavier, relatively, than the liver in the newly-born fish, and that the very rapid growth which seems to take place immediately after birth may be at the expense of the material stored in the liver. Reach (1912) finds that, in Torpedo, the embryo collects reserve fat in the liver, at the expense of the yolk.

During the exploratory voyages for Hake organised by the Fleetwood NEW SERIES.-VOL. XVI. NO. 2. MAROH, 1930. 
Fishing-Vessel Owners' Association, in March, April, and May, 1927, I was able to make some weighing experiments on Dogfish at times when this fish was being caught, but when Hake were few or absent. The liver only was weighed. The results were read at the meeting of the British Association (Section D) at Leeds, in August, 1927. Owing to the fact that the data were too scanty to be grouped in $10-\mathrm{cm}$. categories, the mean value for the coefficient $k$ in all the fish in the sample is used. Full data are given in the Appendix, Table XIX. The results are shown in Figure 14.

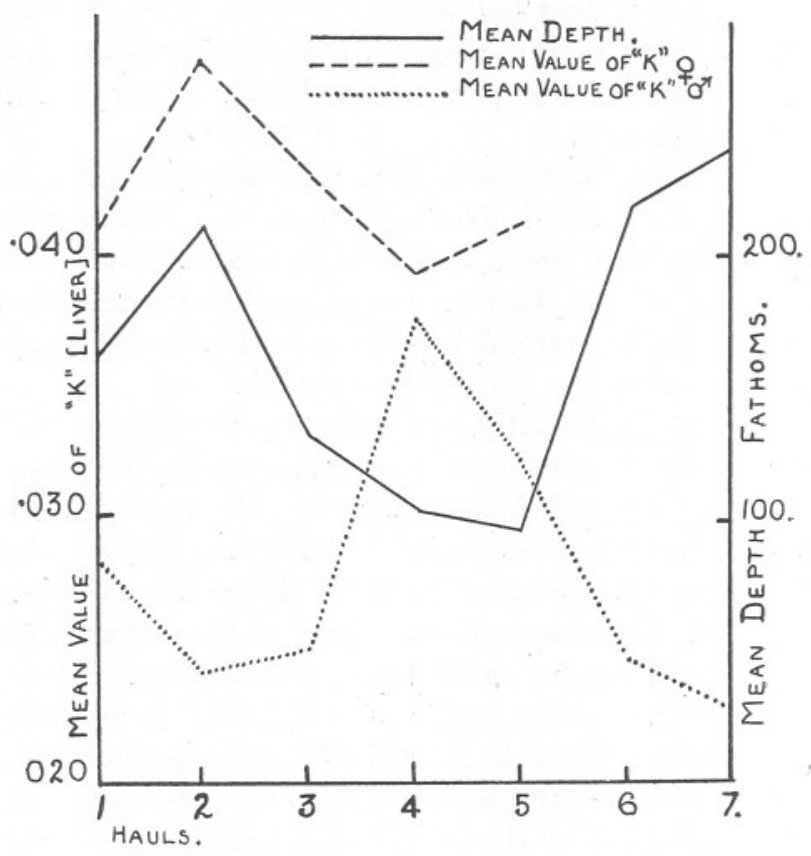

Fig. 14.-Curves showing the correlation between mean depth, and mean value of $k$ (liver), in males and females. Florence Brierley, April, 1927. Data in Table XIX.

The numbers along the abscissa are the serial numbers of the hauls, in the order in which they were made in the Faroe-Shetland Channel. These numbers may be compared with the numbers in the Appendix, ${ }^{*}$ from which the details of the hauls may be gleaned. The ordinates represent the mean value of the coefficient $k$ (liver) (scale on the left), and the mean depth of haul (scale to right).

Three curves are drawn. The continuous line represents the mean depth, the pecked line the mean value of $k$ (liver) in the females, and the dotted line the mean value of $k$ (liver) in the males.

There is a direct coincidence between the mean value of $k$ (liver) and the 
depth of haul in the female, and in this respect the work on the Florence Brierley confirms well the results of the George Bligh. A second point in which the two sets of experiments confirm one another is in the much smaller mean weight of the liver in the male as compared with the female. Where they differ entirely is in the relation between the mean value of $k$ (liver) and the mean depth of haul, in the males. Whereas in the experiments on the George Bligh we found that the mean weight of the liver increased with increase of depth, in the experiments on the Florence Brierley the reverse was true, and there was a strikingly good inverse

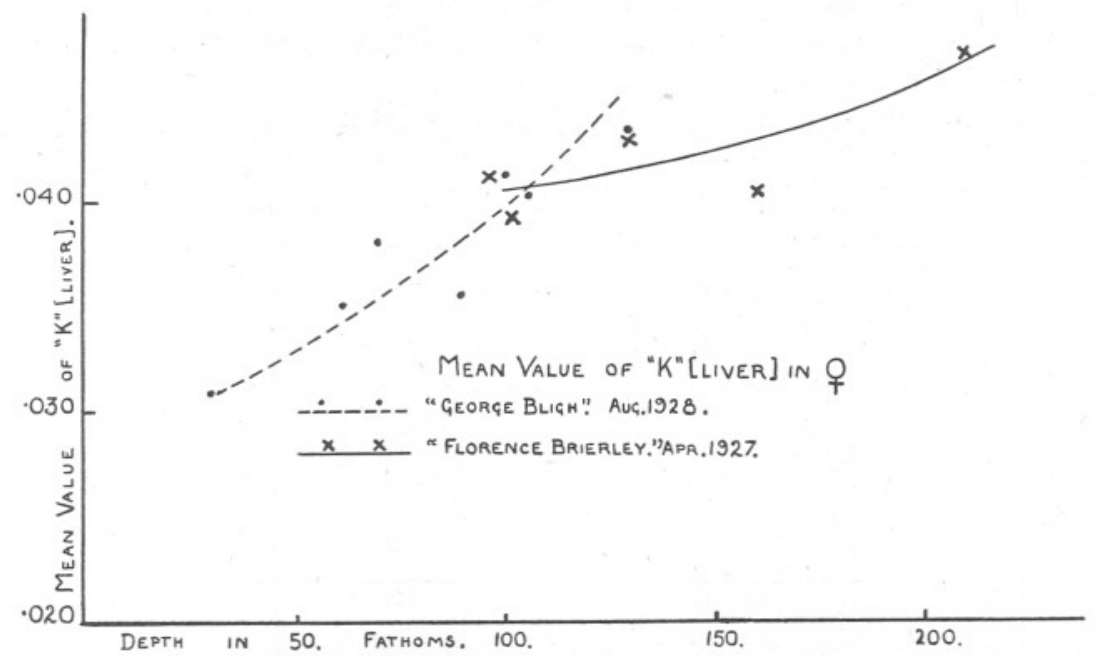

FIG. 15.-Curves drawn roughly through the plotted points for increase in mean value of $k$ (liver), with increase of depth. Females. George Bligh and Florence Brierley. Data in Tables XVIII and XIX.

relation between the mean depth of haul and the mean value of the coefficient $k$ (liver).

In Figure 15 free-hand curves are drawn through the plotted points for mean value of $k$ (liver) in the immature and non-pregnant females from the George Bligh series of observations (black dots), and from the Florence Brierley series (crosses). As the table in the Appendix shows, the mean length of the females in the Florence Brierley samples varied between 74.7 and $83.9 \mathrm{~cm}$., hence they have been compared with the lengthcategory 70-79 $\mathrm{cm}$. in the George Bligh series. A further point to notice is, that, in the Florence Brierley samples, pregnant and non-pregnant females have not been distinguished; but, as has been stated, there was no difference in the mean value of $k$ (liver) in pregnant and non-pregnant females.

Figure 15 shows that the two series of samples give free-hand curves 
which are very similar and reasonably continuous. The curve derived from the Florence Brierley samples is decidedly flatter than that derived from the George Bligh samples, but one may say that, on the whole, the Florence Brierley samples, which continue into deeper water than the George Bligh samples, also continue the upward slope of the curve for mean value of the coefficient $k$ (liver).

In Figure 16 are drawn the corresponding curves for males in the two series of samples. As in the females, the males in the Florence Brierley samples are compared with the males of 70-79 $\mathrm{cm}$. in the George Bligh samples, since the males in the former have a range in mean length of $70 \cdot 3$ to $74 \cdot 6 \mathrm{~cm}$., or very similar to that of the males of $70-79 \mathrm{~cm}$. in the George Bligh samples.

Owing chiefly, no doubt, to the difficulty of assigning a correct mean

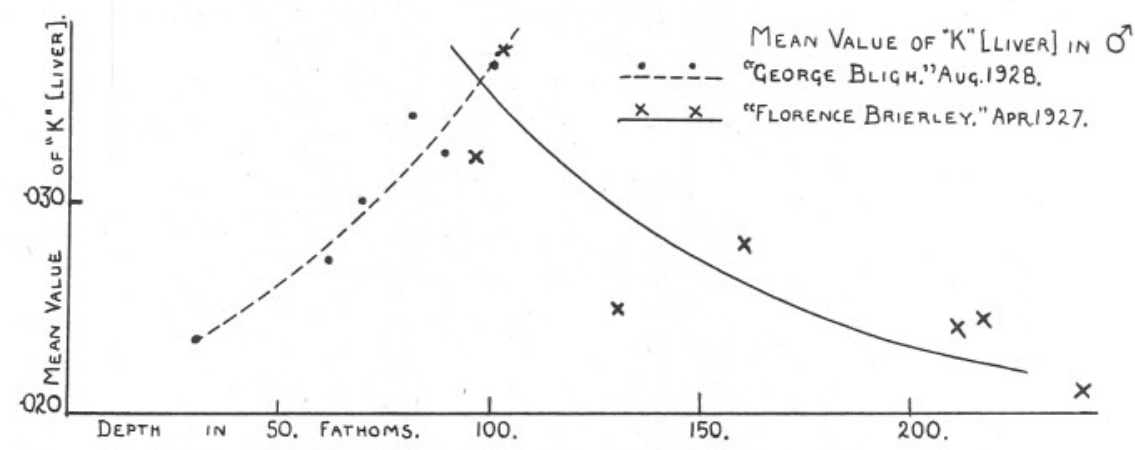

Fig. 16.-Curves drawn roughly through the plotted points for increase in mean value of $k$ (liver), with increase of depth. Males. George Bligh and Florence Brierley. Data in Tables XVIII and XIX.

depth of haul to the hauls made on the slope, which is very steep beyond 150 fathoms in the Faroe-Shetland Channel, the plotted points for the Florence Brierley males are scattered somewhat irregularly as compared with the George Bligh males. None the less, where the depths worked by the two expeditions meet, at $90-110$ fathoms, their plotted points are in good agreement, and the two curves are wholly comparable.

Figure 16 therefore shows that, in male dogfish, the mean value of $k$ (liver) increases, with increase of depth, to a depth between 90 and 110 fathoms. At depths greater than this, the mean value of $k$ (liver) decreases with increase of depth.

In the first section it has been stated that, at or over very great depths, were found shoals of exclusively male dogfish; these may certainly be regarded as having been taken in midwater during the hauling or shooting of the trawl. In my report on the fishes taken by the Florence Brierley (Hickling, 1928), I have shown that Acanthias was taken at 
every depth fished, from $90-100$ to 500-520 fathoms. At depths greater than about 250 fathoms, males alone were taken. Hjort (1912) records the finding of Acanthias vulgaris living pelagically over very great depths north of the Faroes. Hence it would appear that, possibly at all depths, and certainly over the very deep water in the region of the continental slope, the spur-dog can, and does, live pelagically.

Figures 15 and 16 should therefore be interpreted thus, in my view. The females are bottom-living to a greater extent than the males, and, while it is possible that, as indicated, perhaps, by the flattening of the curve, in Figure 14, beyond 100 fathoms, they become to some extent pelagic in deeper water, the males certainly do so beyond this depth, and, from this depth toward deeper water, tend to live more and more pelagically, that is, for an increasingly large proportion of the fish to have been taken at depths intermediate between surface and bottom. This would explain the progressive decrease in mean weight of the liver in the males, with apparent increase of depth, beyond about 100 fathoms ; it is entirely consistent with the curious segregation of males alone in, or over, very deep water. But this will be touched on again in the discussion.

\section{DISCUSSION.}

As a result of the study of the length-distributions of the dogfish at the various stations, it was concluded that (1), the fish are segregated according to size in such a way that the smaller fish are found in shallower, the larger in deeper water; (2) the males are found in shallower water than the females of the same size; and (3) the pregnant females make a migration into shallow water, passing through the shoals of dogfish of smaller sizes, to bear their young.

This graduation according to size is well known among fishes. Thus, Meek (1916) writes, of fish in general, "after a period in relatively shallow water, and this period is generally the summer, the shoal migrates to deeper water. At first, the migration is not to a great distance, but with growth the annual pulsation becomes greater and greater." Of the Spurdog he writes, "the young of the species measure 22 to $25 \mathrm{~cm}$., and they remain inshore during the summer. . . . They do not appear to migrate far from the coast in the first winter. The migrations are local during the phase of immaturity, and when the dogfish reach maturity, they tend to migrate into shallow water in summer, and to deep water for winter, keeping together in large companies."

Ford (loc. cit.) made notes on the composition of the dogfish shoals occurring off Plymouth. His samples were taken by fishing vessels, hence, as might be expected, he makes no mention of very small newlyborn fish. From November 26th to July 29th his samples consisted of 
"medium-sized fish, of which the majority were immature females," and "immature fish in which males and females were equal in number." The range in length seemed to be from 36 to $60 \mathrm{~cm}$., and usually 40 to $60 \mathrm{~cm}$. This is what one would expect in samples from shallow water. The inward migration of the pregnant females in the autumn is clearly indicated by his samples 11, 12, and 1, in August and early November. The withdrawal of the females after the birth of their young is indicated by the statement that " towards the end of November, it became noticeable that . . . the proportion of the conspicuously large fish was diminishing." Ford's conclusion that "Size and sexual condition are important factors in the constitution of the shoals in this species, the former probably being the more influential one," is also in entire agreement with my results, and I consider that the two sets of observations confirm one another in a very satisfactory way. His sample 2 , from the catches of a steam-trawler, in which only $19.8 \%$ of females were present, can be explained by the assumption that she was fishing in a region where, as on the Cockburn Bank in our samples, males greatly predominated as a result of the segregation of the dogfish by size, and the concentration of the older year-classes of males at a certain depth, as explained earlier in this paper. The observation of Borcea (1905) that only females are found off Roscoff in the summer, is probably a further observation on the inward migration of the pregnant females. Quigley (1928), however, finds that the shoals of the Pacific dogfish " consisted of both sexes, and all sizes of fish, or else the 'baited set-line' had been visited within a few hours by several different shoals." Especially significant is his observation that " the largest fish were usually taken at a greater depth than the smallest, and it may be that the composition of the shoals is in part determined by size."

The study of the variations in "condition" of the dogfish led to the conclusion that, although indefinite and even contrary results were found in the Banks-Westward region, there is, in the liver, and perhaps to a less striking degree in the flesh, a relation between depth and "condition" in males, immature females, and pregnant females. The "condition" improves from shallower to deeper water.

It should be emphasized that this is no mere "statistical figment"; the work was commenced as a result of the obvious difference in size and oiliness between the livers of dogfish taken in deep, and shallow water, a difference most noticeable on dissection.

Polimanti (1915) investigated the fat-content of a number of fishes from a variety of habitats, and found that the fat-content decreased with increase of depth, in such a way that pelagic fish had the highest fatcontent, and that bottom-living fishes had a fat-content decreasing as the depth of the habitat increased. Deep-sea fishes, of which, however. he 
was able to analyse only one species, the bathypelagic $C y c l o t h o n e ~ m i c r o d o n$, had the lowest fat-content. He was of the opinion that a high fat-content supplements the swim-bladder as an agency of flotation, in fact, that the functional relations between the swim-bladder and the fat and water content are very intimate. He quotes the well-known relation between fatcontent and vertical movement in fish eggs and larvæ, and also quotes those authors who have shown that, in Clupeidæ, there is a relation between fat-content and depth : in the summer they live at the surface, and are rich in fat, while in the winter they live in the depths, and are poor in fat.

In a paper to Section D of the British Association in 1927, I pointed out that, since the liver in the dogfish is known to consist largely of oil, a fish with a large liver must be relatively lighter, in relation to the water in which it swims, than a fish with a small liver. The liver, in fact, must act more or less as an organ of flotation, just as Polimanti suggested for fat in general among fishes.

During the 1928 cruise of the George Bligh I made direct determinations of the specific gravity of dogfish. The loss in weight on weighing the fish first in air, and then in sea-water, was used for calculating the specific gravity. The results are given in Table XX. The weighted mean value of $k$ (liver) is also given for comparison. The specific gravities are the means of a good number of determinations in each case, made during the most favourable weather conditions. In Table XX the stations at which these determinations were made are arranged in order of depth.

TABLE XX.

Variations in Weighted Mean Value of $k$ (LIVer), and in Specific Gravity. GEORGE BLIGH, 1928.

\begin{tabular}{|c|c|c|c|c|c|}
\hline \multirow{3}{*}{$\begin{array}{l}\text { Station. } \\
\text { Inside Aran Islands }\end{array}$} & \multirow{3}{*}{ Depth. } & \multicolumn{2}{|c|}{ Male. } & \multicolumn{2}{|c|}{ Female. } \\
\hline & & $\begin{array}{l}\text { Weighted mean } \\
\text { value of } k \text { (liver). }\end{array}$ & $\begin{array}{l}\text { Mean speciflc } \\
\text { gravity. }\end{array}$ & $\begin{array}{l}\text { Weighted mean } \\
\text { value of } k \text { (liver). }\end{array}$ & $\begin{array}{l}\text { Mean specific } \\
\text { gravity. }\end{array}$ \\
\hline & & - & - & .0234 & $1 \cdot 044$ \\
\hline Bantry Bay & 30 & .0229 & $1 \cdot 046$ & .0256 & $1 \cdot 037$ \\
\hline Galway Bay & 55 & - & - & .0265 & $1 \cdot 036$ \\
\hline Galley Head & 61 & $\cdot 0266$ & $1 \cdot 040$ & $\cdot 0303$ & $1 \cdot 038$ \\
\hline "Station 18 " & 69 & $\cdot 0310$ & $1 \cdot 044$ & $\cdot 0325$ & $1 \cdot 034$ \\
\hline Outer Fastnet & 100 & $\cdot 0340$ & $1 \cdot 043$ & $\cdot 0407$ & $1 \cdot 037$ \\
\hline Testward & 105 & $\cdot 0350$ & $1 \cdot 040$ & $\cdot 0359$ & $1 \cdot 040$ \\
\hline Mean & & & $1 \cdot 043$ & & $1 \cdot 038$ \\
\hline
\end{tabular}

Table XX shows in quite a striking degree the increase in the index of condition, with increase of depth, in both sexes. In the males, the specific gravity tends to decrease with increase of depth, but the females show no relation between the specific gravity and depth. It is possible, however, that the development of the very large eggs, and pregnancy, serve to discount the effect of local differences in the buoyancy of the 
liver. None the less, the females have a consistently lower specific gravity than the males, which is in good agreement with their consistently heavier and larger liver. This seems to support the hypothesis that the condition of the liver affects the specific gravity.

Masterman (1911) reports on the specific gravity of the Plaice, and found that this decreases with increase of depth, especially in the females where it decreases from 1.077 at depths of less than 20 fathoms, to 1.068 at 30 to 40 fathoms. According to these experiments, in the Plaice, as in male dogfish, the fish are lighter, relatively to the water in which they swim, in deeper than in shallower water.

My observations are confined to weighings only, and no chemical analyses have been possible. But there is no reason to doubt but that the increase in the bulk of the liver, which takes place in the deep, as compared with the shallow water, is due to an accumulation of fat. Therefore my results contradict Polimanti's, except, perhaps, in the females of the Banks-Westward series, and in the males in the deep water of the FaroeShetland Channel, where the liver decreased in weight with increase of depth. But it is difficult to see how Polimanti's general conclusion can be upheld in the case of the deep-sea bathypelagic selachians. In Scymnorhinus lichia, for example, the liver is enormous: it fills the bodycavity, and may even protrude through the abdominal pores. The liver of this shark is very rich in oil. I have some data on the weight of the liver in the deep-sea selachian Spinax niger.

During a voyage on the Cardiff steam-trawler Nogi in January, 1928, I weighed the livers of 30 mature specimens of Spinax, ranging from 34 to $45 \mathrm{~cm}$. in length. The mean value for the coefficient $k$ (liver) was $\cdot 0736$, and the weight of the liver amounted to $24 \%$ of the weight of the fish. The range in depth of Spinax, according to my observations on the Florence Brierley, is from 120 to 400 fathoms, and of Scymnorhinus from 220 fathoms to at least 520 fathoms (Hickling, 1928). Hence it is plainly incorrect to assume that deep-sea fish are poor in fat-indeed, among selachians, at least, the reverse seems true, for the highest mean value for the coefficient $k$ (liver) in Acanthias was $\cdot 0409$ (Bull, 130 fathoms), which is far less than the figure of $\cdot 0736$ quoted above for Spinax.

Channon (1928) has analysed the liver oils from a considerable number of species of fish, and gives, in tabular form, the percentage of unsaponifiable matter in the oils. Of especial interest is his Table III, in which those members of the Selachii which he examined are arranged in order of decreasing content of unsaponifiable matter. It is plain that these fish are also arranged in decreasing order of depth. The deep-sea sharks Scymnorhinus, Lepidorhinus, and Spinax, have very high values, the shallow water sharks Lamna, Scyllium, and Galeus, have very low values for percentage of unsaponifiable matter; while Acanthias and Notidanus 
have intermediate values. It seems reasonable to suggest that a modification in metabolism, with reference to depth, which takes place in the Selachii as a group, may also take place in a single species; and that the increase in mean weight of the liver, with increase of depth, observed in Acanthias, may be due to an increasing quantity of unsaponifiable matter. The point will be tested, if opportunity offers.

We may now put side by side the main facts relating to the distribution of the dogfish on the one hand, and the condition, with especial reference to the liver, on the other.

(1) The fish are segregated according to depth, so that the smaller fish are found in shallower water, the larger in deeper water.

(2) The males are found in shallower water than the females of the same size.

(3) The pregnant females migrate from deep to shallow water to bear their young.
(1) The coefficient of condition in the liver is higher in larger than in smaller fish.

(2) The malès have a lower coefficient of condition in the liver than the females.

(3) Pregnant females have a lower coefficient of condition in the liver than non-pregnant females, the difference increasing with decrease of depth.

When it is remembered that the coefficient of condition increases with increase of depth quite independently of the increase due to the greater mean length, these three pairs of facts fall surprisingly into line. The large fish have a higher coefficient of condition than the small fish, and are found in deeper water ; the females have a higher coefficient of condition than the males, and are found in deeper water than the males of the same size ; and, finally, the pregnant females are found to lose condition as they migrate from deep to shallow water.

On the other hand, we have seen that, in the Banks-Westward region, the dogfish were present in deeper water than those of the same size in the Fastnet region (Section I), yet, as Tables IV and V show, the mean values for the coefficient $k$ (liver) are lower, not higher, in the Banks-Westward than in the Fastnet series.

It is not suggested that the "condition " is responsible for the distribution : it is hard to see how this could be the case. The only conceivable manner in which condition might affect the vertical distribution of the fish would be, as Polimanti suggested, by its effect on specific gravity. But dogfish with a lower specific gravity are found in deeper water, not in shallower water, as Polimanti's hypothesis demands. It might also be suggested that the inward migration of the pregnant females is due to the drain on the resources of the liver, causing a loss in condition, and therefore a movement into shallower water, but, in deeper water, the condition 
of pregnant and of non-pregnant females differs only slightly, the difference, however, becomes progressively greater as the water becomes shallower. The "condition" would seem to be rather a consequence of the distribution, than a cause of it.

Borley (1912) found that there was a correlation between distribution and condition in Plaice, such that the smaller Plaice were in better condition in shallower water than in deeper water; the medium-sized Plaice were in better condition at intermediate depths than in either deep or shallow water; while large Plaice were in their best condition in deep water. He suggests that "grounds of different depth . . . are suitable to the nourishment of Plaice of different sizes, the size increasing with depth."

This hypothesis might be applied to the dogfish. If shallower water is better suited to the nourishment of small dogfish than deeper water, then they will tend to collect and remain in shallow water, and to be in their best condition there. In Figures 9 and 12, for instance, the curves tend to intersect so as to indicate that, although the larger fish in the samples have heavier livers in the deep than in the shallow water, among the smaller fish the reverse may be the case. Unfortunately, fish smaller than $50 \mathrm{~cm}$. were not weighed. But the hypothesis would also have to explain the tendency for the males to be found in shallower water than the females of the same size, and to explain the loss of weight during the inward migration of the pregnant females.

Such notes as have been made on the stomach-contents of the dogfish do not support the idea that the deeper water provides more suitable food for the larger fish than the shallower water.

In the very shallow water stations inside the Aran Islands (21 fathoms) and in Bantry Bay ( 30 fathoms), the food consisted of herrings, small horsemackerel, garfish (Belone), and whiting ; in Galway Bay (55 fathoms) and oft Galley Head (61 fathoms), herrings, mackerel, horse-mackerel, whiting, bib (Gadus minutus), "smelt" (Argentina sphyrana), and Eupagurus, were found in the stomachs ; while on the Westward ground (105 fathoms), the food consisted of large horse-mackerel, blue whiting (Gadus Poutassou), and squids. The presence of herrings, mackerel, and garfish in the shallower water would seem to provide a richer fare than the large horsemackerel, blue whiting, and squids in the deeper water.

Of course, a loss of condition can be the result of rapid growth in length, as well as of an environment less favourable to the nutrition of the fish. But if the poorer condition of the dogfish in the shallower water were due to their more rapid growth, one would expect that the fish in the shallower water would be larger than those in the deeper water, whereas the reverse is found.

The shoaling of the dogfish by size is easily understandable on Ford's 
suggestion that it is more advantageous for fishes of the same size to congregate together, since, in shoals of fish of very varying sizes, it is probable that the small fish would suffer disadvantage, for instance, in their chances of obtaining food. The presence of the very small fish in shallow water is the consequence of their having been born there. But the persistence of the small fish in shallower water, and the very perfect graduation with depth according to size, calls for a special explanation.

A tentative modification of Borley's hypothesis is here suggested. It seems possible that depth itself involves some factor, or factors, tending to modify metabolism in the direction of greater storage of reserve material, and in an increase both in the proportion, and in the actual quantity, of unsaponifiable matter in the liver. The value of one unsaturated hydrocarbon, squalene, as a reserve material, is attested by its presence in the egg-oils of some Selachians. Heilbronn, Kamm, and Owens (1926) found that the young eggs of Spinax contained squalene, and that it was absorbed during the development of the embryo. Temperature may play its part, though the difference in temperature as between deep and shallow water is usually slight. However, in the deeper water there is a greater uniformity of temperature than in the shallower water. Pressure itself may be a factor of importance. This suggestion certainly derives some support from the hake, which retires to deep water during its exhaustion after spawning, and, in the conditions found there, makes a rapid recovery. (Hickling, 1930.)

As sexual maturity in the dogfish approaches, the fish tend to find the depth best suited to the accumulation of reserve material, rather than for growth alone, and thus, according to my hypothesis, seek deeper water. The more katabolic males, in which, in any case, the strain of reproduction is much less severe than in the females, will not need to seek such deep water as the more anabolic females, if the greater depths have an increasingly beneficial effect. Finally, the inward migration of the pregnant females carries them into depths less favourable to the replenishment of the reserve material, which is being withdrawn both to supply the energy for migration, and to nourish the young. There is thus a heavy loss in condition.

In this way, the "condition " might be the result of the distribution, and the distribution the result of the tendency of the fish to place itself in the most favourable conditions to satisfy its present metabolic needs.

While this hypothesis may go some way to meet the facts, it is always possible that the correlation of condition and depth may be dependant on some factors in the life-history of the fish, of which we are at present ignorant. 
It may be added, finally, that the Spur-dog is a hardy fish, which would seem well suited to physiological experiments, and especially experiments on metabolism.

\section{SUMMARY.}

In August, 1928, dogfish were measured at a series of stations to the south, south-west, and west of Ireland. A relation was found between size and depth, such that the smaller fish were most abundant in the shallower water, the larger fish in deeper water. This relation was broken only by the pregnant females, fish generally over $80 \mathrm{~cm}$. in length, which were in process of migration into shallow water to bear their young.

The male dogfish were present in shallower water than the females of the same size.

The sex-ratio varied with depth. In shallow water there was a slight predominance of females, at intermediate depths a predominance of males, and in deep water a gradually increasing predominance of females. This predominance of males at intermediate depths is liable to be masked by the inward migration of the pregnant females. [Over very deep water in the Faroe-Shetland Channel, in March, 1927, shoals of dogfish, consisting exclusively of mature males, were found.]

Weighing experiments were made both in the Faroe-Shetland Channel and off Ireland. The mean weight of the liver, and to a lesser degree, of the flesh, was greater in deep than in shallow water. That is, the fish were in better condition in the deep than in the shallow water. Exceptions were found both in the series of Irish stations and in the Faroe-Shetland Channel. [In the very deep water worked in the last-named region, the index of condition of the liver in the males decreased with increase of depth. It is suggested that this apparent progressive decrease in condition with increase of depth is actually due to an increasingly large proportion of the fish having been taken in midwater during the hauling and shooting of the trawl.]

The condition of the liver improves with increase of length, in both sexes : the livers of female dogfish are in better condition than those of male dogfish taken under the same conditions. Pregnant females lose condition during the migration from deep to shallow water. In the deep water they have an index of condition almost as high as non-pregnant females. Generally speaking, pregnant females have a lighter liver, but heavier flesh, than non-pregnant females.

These variations in condition are related to the distribution of the dogfish, but, in the discussion, it is concluded that the condition is the result of the distribution, rather than the cause of it, as Polimanti suggests. The better condition of the fish in deeper water is regarded as 
due to an effect of depth, possibly pressure, on the metabolism of the fish, favouring anabolism rather than katabolism. Under the increased metabolic strain of maturity, the larger fish may therefore seek deeper water, the more anabolic females to a greater extent than the more katabolic males.

Female dogfish have a lower specific gravity than the males, in agreement with their larger liver.

The index of condition of the liver is much higher in Embryos than in newly-born dogfish, and it is suggested that a sudden spurt of growth takes place immediately after birth, at the expense of the material stored in the liver of the embryo.

\section{LITERATURE CONSULTED.}

Belloc, G. 1922. Notes sur la croissance du Merlu. Rapport Atlantique, 1922. Cons. Perm. Exp. Mer.

Birtwistle, W., and Lewis, M. 1924. Hake investigations. Report Lancashire Sea Fisheries Laboratory, 1924.

Borcea, J. 1905. Recherches sur le systeme urogenital des elasmobranches. Arch. Zool. Exper. Paris, 1905.

Borley, J. O. 1912. A comparison of the condition of the Plaice of different regions as to weight. 4th report, Southern Area, Fishery Investigations, 1909.

Channon, H. J. 1928. The Biological Significance of the Unsaponifiable Matter of oils. III. Fish-Liver oils. Biochem. Jourtal, Vol. XXII, No. 1, 1928.

Ford, E. 1921. A contribution to our knowledge of the life-histories of the dogfish landed at Plymouth. Journ. Mar. Biol. Assoc., N.S., Vol. XII, p. 468.

Hecht, Selig. 1913. The relation of weight to length in the Smooth Dogfish Mustelus canis. Anat. Record, Vol. 7, pp. 39-42.

Heilbronn, I. M., Kamm, E., and Owens, W. 1926. The Unsaponifiable matter from the Oils of Elasmobranch Fish. Part I. Jour. Chem. Soc., CCXIII, p: 1630, 1926.

Hickling, C. F. 1928. The Exploratory Voyages of the Florence Brierley. Notes on the Fish recorded. Ann. Mag. Nat. Hist., Series 10, Vol. II, p. 196.

Hickling, C. F. 1930. Fishery Investigations. Ser. II, Vol. XI (in Press).

Jenkins, J. Travis. The Fishes of the British Islands. Warne, London, 1925. 
Masterman, A. T. 1911. Report on Research in relation to the Plaice Fisheries. Vol. IV. Biological Statistics. Age and Sex. Rept. of research work of the Board of Agriculture and Fisheries, 1905-6. 1911.

MeEk, A. 1916. The Migrations of Fishes. Arnold, London, 1916.

Murray, Sir J., and HJort, J. 1912. The Depths of the Ocean. Macmillan \& Co., London, 1912.

Polimanti, O. 1915. Uber den Fettgehalt und die biologische Bedeutung desselben fur die Fische usw. Biochem. Zeit., Vol. 69 (1915).

Quigley, J. P. 1928. Observations on the Pacific Dogfish. Biol. Bull. Wood's Hole, Vol. LV, No. 6.

REACH, F. 1912. Untersuchungen uber das Verhalten der Fette bei Torpedo wahrend der Graviditat. Biochem. Zeit., Vol. 40.

Saemundsson, B. 1923. On the age and growth of the Cod in Icelandic waters. Meddelelser f. Komm. f. Havunders. Ser. Fisk., Bd. VII, 3.

Wallace, W. 1907. Report on Age and Growth-Rate of Plaice in the Southern North Sea. 2nd Rept. Southern Area, 1904-1905.

Wollaston, H. J. B., and Hodgson, W. C. 1929. A new method of treating Frequency-curves in Fishery Statistics. Jour. du Conseil., Vol. IV, 2. 


\section{APPENDIX}

TABLE XIII.

Measurements of Dogfish at the Stations. George Bligh, August, 1928.

Upright figures denote frequency, italic figures denote percentage frequency.

Banks-Westward Region.

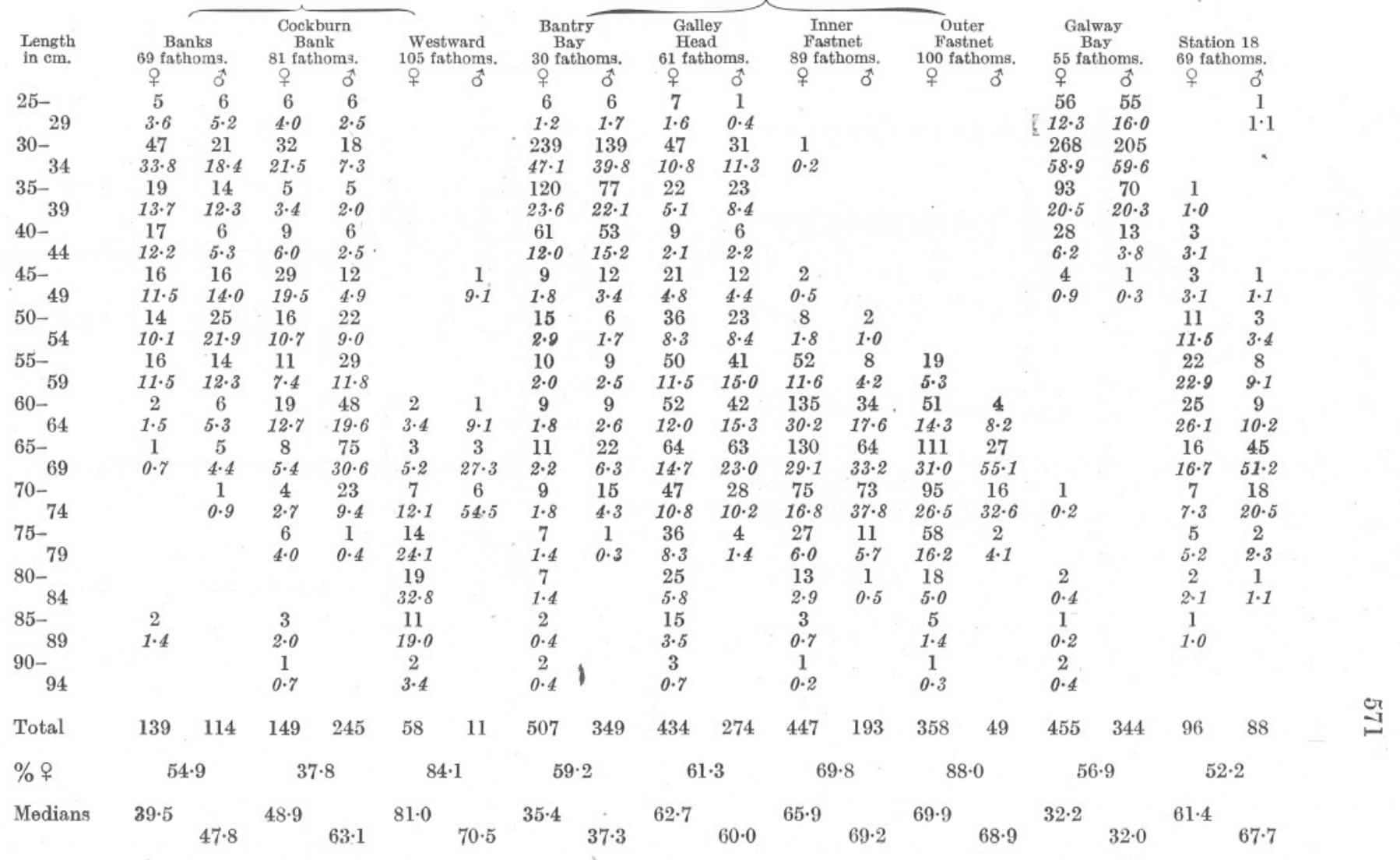




\section{TABLE XIV.}

Florenoe Brierley Dogfish. Faroe-Shetland Channel.

\begin{tabular}{|c|c|c|c|c|c|c|c|}
\hline $\begin{array}{l}\text { Date } \\
1927 .\end{array}$ & $\begin{array}{l}\text { G.M.T. of } \\
\text { haul. }\end{array}$ & $\begin{array}{c}\text { Mean } \\
\text { depth. } \\
\text { Fathoms. }\end{array}$ & $\begin{array}{l}\text { Nur } \\
\text { males. }\end{array}$ & $\begin{array}{l}\text { er of } \\
\text { females. }\end{array}$ & $\begin{array}{l}\text { Per cent of } \\
\text { females. }\end{array}$ & $\begin{array}{l}\text { Number of } \\
\text { pregnant } \\
\text { females. }\end{array}$ & $\begin{array}{l}\text { Per cent of } \\
\text { pregnant } \\
\text { females. }\end{array}$ \\
\hline March 25 & 1500 & 300 & 100 & 4 & 4 & - & - \\
\hline,$\quad 27$ & 0800 & 119 & 3 & 5 & 63 & - & - \\
\hline , 28 & 1700 & 101 & 9 & 22 & 71 & - & - \\
\hline$\Rightarrow \quad 28$ & 2005 & 106 & 23 & 38 & 62 & - & - \\
\hline$\Rightarrow \quad 29$ & 0815 & 105 & 12 & 37 & 75 & - & - \\
\hline,$\quad 29$ & 1510 & 160 & 11 & 28 & 72 & - & - \\
\hline$\Rightarrow \quad 29$ & 1745 & 210 & 5 & 45 & 90 & 18 & 57 \\
\hline " 30 & 1800 & 130 & 27 & 17 & 39 & 10 & 59 \\
\hline$" \quad 31$ & 1245 & 102 & 5 & 33 & 87 & 6 & 18 \\
\hline April 2 & 1930 & 96 & 10 & 35 & 78 & 4 & 12 \\
\hline 3 & 2115 & 216 & 41 & 0 & 0 & - & - \\
\hline 5 & 0800 & 240 & 24 & 2 & 8 & 2 & 100 \\
\hline
\end{tabular}

\section{TABLE XV.}

August, 1929. Maturity of Male Dogfish. All Stations Combined. Based on Development of Claspers.

\begin{tabular}{ccccc}
\multicolumn{5}{c}{ Numbers of } \\
\cline { 2 - 5 } Length. & Immature. & $\%$ & Maturc. & $\%$ \\
52 & 21 & 100 & & $0 \cdot 0$ \\
53 & 10 & 100 & & $0 \cdot 0$ \\
54 & 9 & 100 & & $0 \cdot 0$ \\
55 & 10 & $90 \cdot 9$ & 1 & $9 \cdot 1$ \\
56 & 10 & $90 \cdot 9$ & 1 & $9 \cdot 1$ \\
57 & 8 & $72 \cdot 7$ & 3 & $27 \cdot 3$ \\
58 & 4 & $66 \cdot 6$ & 2 & $33 \cdot 4$ \\
59 & 7 & $58 \cdot 3$ & 5 & $41 \cdot 6$ \\
60 & 4 & $33 \cdot 3$ & 8 & $66 \cdot 7$ \\
61 & 4 & $26 \cdot 6$ & 11 & $73 \cdot 4$ \\
62 & & $0 \cdot 0$ & 12 & $100 \cdot 0$ \\
63 & 1 & $4 \cdot 5$ & 21 & $95 \cdot 5$ \\
64 & & $0 \cdot 0$ & 23 & 100 \\
65 & & $0 \cdot 0$ & 11 & 100 \\
66 & & $0 \cdot 0$ & 17 & 100
\end{tabular}


Table XVI.

Onset of Pregnancy in Female Dogfish. All Stations, GEorge Bligh, August, 1928.

\begin{tabular}{cccc}
$\begin{array}{c}\text { Length } \\
\text { Group. }\end{array}$ & $\begin{array}{c}\text { No. of } \\
\text { Females. }\end{array}$ & $\begin{array}{c}\text { No. of } \\
\text { Pregnant } \\
\text { Females. }\end{array}$ & $\begin{array}{c}\text { Per cent } \\
\text { Pregnant. }\end{array}$ \\
\hline $55-59$ & - & 0 & 0 \\
$60-64$ & 44 & 1 & $2 \cdot 3$ \\
$65-69$ & 41 & 1 & $2 \cdot 4$ \\
$70-74$ & 49 & 6 & $12 \cdot 2$ \\
$75-79$ & 29 & 6 & $20 \cdot 7$ \\
$80-84$ & 49 & 33 & $67 \cdot 4$ \\
$85-89$ & 35 & 31 & $88 \cdot 6$ \\
$90-94$ & 11 & 10 & $90 \cdot 9$
\end{tabular}

TABLE XVII.

All Stations, George Bligh, August, 1928. Frequencies of Embryos and Free-living Young.

$\begin{array}{ccc}\text { Length. } & \text { Embryos. } & \begin{array}{c}\text { Free-living } \\ \text { Young. }\end{array} \\ 18 & 1 & \\ 19 & 4 & \\ 20 & 13 & \\ 21 & 34 & \\ 22 & 48 & \\ 23 & 54 & 1 \\ 24 & 48 & 2 \\ 25 & 24 & 1 \\ 26 & 6 & \\ 27 & 2 & 14 \\ 28 & & 34 \\ 29 & & 106 \\ 30 & & 191 \\ 31 & & 264 \\ 32 & & 244 \\ 33 & & 195 \\ 34 & & 142 \\ 35 & & 94 \\ 36 & & 94\end{array}$




\section{Table XVIII.}

George Bligh, August, 1928. Grouped Results of Weighing Experiments. Liver.

$50-59 \mathrm{~cm}$.

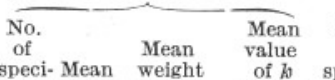

Station.

Banks

Males

*Immature 우

Pregnant

Cockburn Bank

Males

*Immature

Pregnant of

Westward

Males

*Immature

Pregnant 오

Bantry Bay

Males

*Immature 오 Pregnant

Galley Head

Males

*Immature 우

Pregnant

Inner Fastnet

Males

*Immature 우

Pregnant 0

Outer Fastnet

Males

*Immature o Pregnant 우

Inside Aran

Islands

*Immature

Pregnant 9

Galway Bay

Males

*Immature o

Pregnant 0

Bull

Males

*Immature

Pregnant

69

81

105

30

61

89

100

21

130
60-69 cm.

70-79 $\mathrm{cm}$.

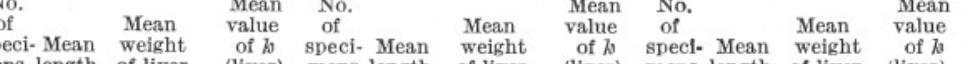

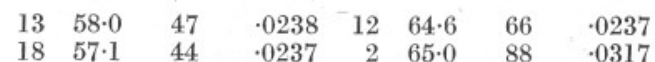

$\begin{array}{rrrrrrrrrrrr}4 & 58 \cdot 3 & 37 & \cdot 0187 & 13 & 64 \cdot 8 & 83 & \cdot 0307 & 3 & 71 \cdot 2 & 123 & .0343 \\ 5 & 56 \cdot 5 & 39 & \cdot 0218 & 12 & 63 \cdot 9 & 73 & \cdot 0279 & & & & \\ & & & & & & & & 2 & 76 \cdot 0 & 75 & .0171\end{array}$

$\begin{array}{rrrrrrrrrrrr}6 & 57 \cdot 2 & 33 & \cdot 0179 & 22 & 66 \cdot 5 & 71 & .0240 & 12 & 72 \cdot 8 & 91 & .0235 \\ 16 & 55 \cdot 0 & 40 & .0234 & 14 & 64 \cdot 7 & 67 & .0250 & 14 & 74 \cdot 3 & 129 & .0310\end{array}$

$\begin{array}{llllllllllll}7 & 56 \cdot 8 & 40 & \cdot 0221 & 23 & 66 \cdot 0 & 81 & .0278 & 6 & 72 \cdot 7 & 106 & \cdot 0275\end{array}$

$\begin{array}{llllllll}10 & 66 \cdot 4 & 98 & .0327 & 15 & 72 \cdot 3 & 123 & .0326\end{array}$ $\begin{array}{llllllll}5 & 84.9 & 156 & .0261 & 3 & 92 \cdot 8 & 125 & .0156\end{array}$

$\begin{array}{llll}3 & 74 \cdot 2 & 109 & \cdot 0264\end{array}$

$\begin{array}{llllllllllll}3 & 76 \cdot 5 & 101 & .0227 & 25 & 85 \cdot 3 & 165 & .0266 & 5 & 92 \cdot 1 & 211 & .0270\end{array}$

90-99 cm.

$\overbrace{\begin{array}{l}\text { No. } \\ \text { of }\end{array} \quad \text { Mean }}^{\begin{array}{c}\text { Mean } \\ \text { value }\end{array}} \overbrace{\begin{array}{c}\text { No. } \\ \text { of }\end{array}}^{\text {Mean }} \begin{gathered}\text { Mean } \\ \text { value }\end{gathered}$
ean er). 
George Bligh, August, 1928. Grouped Results of Weighing Experiments. Flesh.

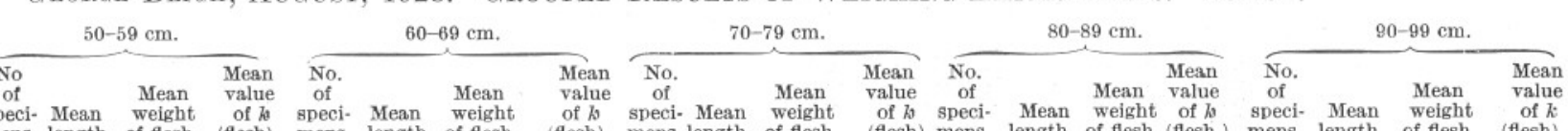

Station.

Banks

Males

*Immature o

Pregnant

Cockburn Bank

Males

*Immature 웅

Pregnant

Westward

Males

*Immature

Pregnant

Bantry Bay

Males

*Immature

Pregnant

Galley Head

Males

*Immature 우

Pregnant

Inner Fastnet

Males

*Immature

Pregnant

Outer Fastnet

Males

*Immature

Pregnant

Inside Aran

Islands

*Immature o

Pregnant

Galway Bay

Males

*Immature 오

Pregnant

Bull

Males

*Immature 우

Pregnant o

Depth, speci- Mean weight of $h$ speci- Mean weight of $k$ speci- Mean weight of $k$ speci- Mean weight of $k$ speci- Mean weight of $k$

$13 \quad 58 \cdot 0 \quad 510 \quad \cdot 261 \quad 12 \quad 64 \cdot 6 \quad 700 \quad \cdot 257$

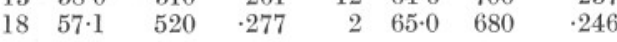

81
$4 \quad 58 \cdot 3$
$530 \cdot 268$
$\begin{array}{llll}13 & 64 \cdot 8 & 820 & \cdot 300\end{array}$
$\begin{array}{llll}3 & 71 \cdot 2 & 1100 \quad \cdot 305\end{array}$

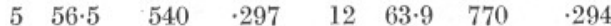
$\begin{array}{llll}2 & 76 \cdot 0 & 1300 & \cdot 296\end{array}$

105

30

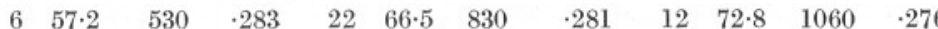

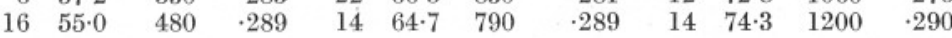

61

$\begin{array}{rrrrrrrr}7 & 56 \cdot 8 & 530 & \cdot 287 & 23 & 66 \cdot 0 & 840 & \cdot 292\end{array}$

$22 \quad 64 \cdot 6 \quad 810 \quad \cdot 292$

$\begin{array}{llll}6 & 72 \cdot 7 & 1090 & \cdot 285\end{array}$

89

$\begin{array}{lllllllll}10 & 66 \cdot 4 & 840 & \cdot 287 & 15 & 72 \cdot 3 & 1130 & \cdot 298\end{array}$

$\begin{array}{llllllllllll}2 & 58.5 & 630 & .313 & 15 & 65 \cdot 8 & 860 & .302 & 10 & 73 \cdot 1 & 1170 & .299\end{array}$

100

$\begin{array}{llllllll}16 & 67.5 & 900 & .290 & 14 & 72 \cdot 2 & 1080 & \cdot 287\end{array}$

$\begin{array}{llll}2 & 81 \cdot 0 & 1800 & \cdot 339 \\ 8 & 84 \cdot 5 & 1960 & -325\end{array}$

$\begin{array}{llll}0 & 83.9 & 1780 & 301\end{array}$

$\begin{array}{lll}2 & 92.5 & 2400\end{array}$

$\cdot 304$

$\begin{array}{llllllllllll}8 & 67 \cdot 3 & 870 & \cdot 287 & 15 & 75 \cdot 2 & 1290 & -301 & 3 & 81 \cdot 5 & 1700 & -315\end{array}$

5

$\begin{array}{llllllll}5 & 84.9 & 1920 & \cdot 315 & 3 & 92 \cdot 8 & 2330 & \cdot 291\end{array}$

$25 \quad 85 \cdot 3 \quad 1910 \quad: 307$

$\begin{array}{llll}5 & 92 \cdot 1 & 2340 & \cdot 299\end{array}$ $\begin{array}{lllll}.297 & 13 & 72 \cdot 3 & 1240 & .325\end{array}$

$\begin{array}{llll}3 & 74 \cdot 2 & 1220 & 297 \\ 3 & 76 \cdot 5 & 1300 & \cdot 291\end{array}$

$\begin{array}{llll}6 & 81 \cdot 7 & 1730 & -318\end{array}$

$5 \quad 82.9 \quad 1780 \quad \nmid 312$

$\begin{array}{llll}4 & 65 \cdot 5 & 830 & .295\end{array}$

$\begin{array}{llll}94.4 & 1330 & \cdot 320\end{array}$

$\begin{array}{lll}86.0 & 2080 \quad .356\end{array}$

$\begin{array}{llll}2 & 82.5 & 1900 & \cdot 339\end{array}$

* Including non-pregnant females. 


\section{Table XIX.}

Florence Brierley. April, 1927. Weighing Experiments.

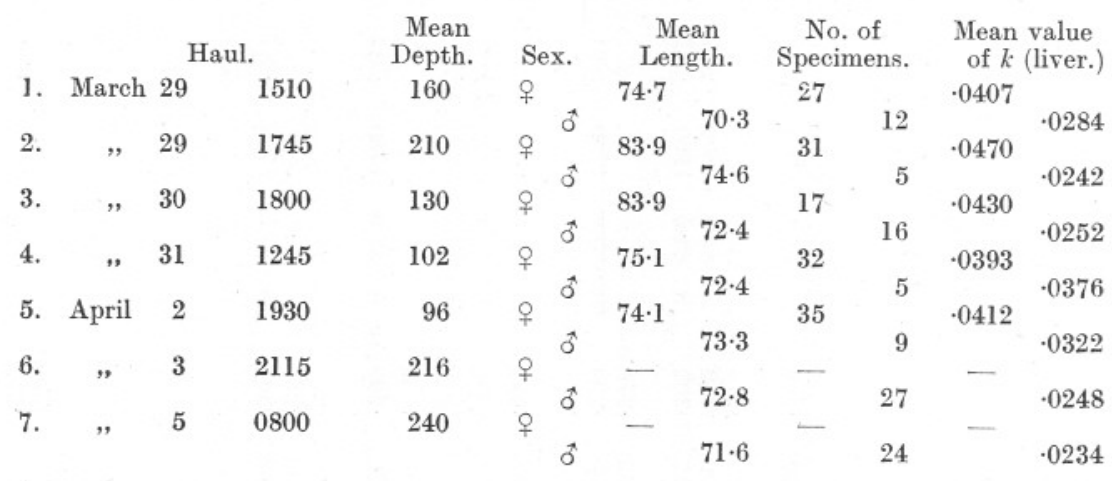

